\title{
Pastoralna, socijalna, kulturna i politička djelatnost franjevaca trećoredaca glagoljaša u Sjedinjenim Američkim Državama
}

Ovaj rad nudi sažetak sedamdeset osmogodišnjeg rada i djelovanja franjevaca trećoredaca glagoljaša u Americi. Ponajprije se daje uvid u povijesnu odluku franjevaca trećoredaca glagoljaša o odlasku za svojim narodom u emigraciju u Sjedinjene Američke Države. Do te odluke došlo je već nakon drugoga jačega vala iseljavanja hrvatskog stanovništva između dvaju svjetskih ratova. Odluka je imala dva cilja: poći za dijelom svoga naroda i održavati ga u vjeri i kulturi iz koje dolazi te pomoći Provinciji pri gradnji samostana u Zagrebu. Potom se govori o pastoralnim aktivnostima franjevaca trećoredaca u povjerenim im župama. Trećoreci su od svog dolaska u Ameriku pa do odlaska djelovali u trima župama u Pittsburghu i okolici: Župi sv. Nikole u sjevernom dijelu Pittsburgha, Župi sv. Nikole u Millvaleu te Župi Presvetog Srca Isusova u McKeesportu. Ponuđen je povijesni osvrt na gradnju i uređivanje crkava te na duhovne, socijalne i kulturne aktivnosti u župama. U drugom dijelu rada govori se o najvažnijim kulturnim i prosvjetiteljskim aktivnostima franjevaca trećoredaca, koji su ostavili značajnijeg traga u Pittsburghu i okolici. Ponajprije se opisuju slike hrvatskog slikara Maksimilijana Vanke, koje je napravio u crkvi sv. Nikole u Millvaleu. Unutrašnjost te crkve, koja je ušla u nacionalni popis povijesnih mjesta u Americi, oslikana je različitim motivima iz Hrvatske, a također je oslikana i teška sudbina hrvatskog emigranta u Americi. Drugi kulturni, odnosno prosvjetiteljski doprinos trećoredaca o kojima je riječ u ovome članku jesu dva mjesečnika, koje je čitav niz godina objavljivao fra Dobroslav Sorić. Jedan je izlazio na hrvatskom jeziku pod imenom Ave Maria, a drugi na engleskom pod naslovom Immaculate Conception. Oba su časopisa bila vjerske naravi; Ave Maria bio je namijenjen svim Hrvatima prve generacije u Americi, dok je Immaculate Conception prvenstveno bio namijenjen djeci naših iseljenika koji su se slabije služili hrvatskim jezikom. U ovom se radu nudi prikaz poteškoća s kojima se susretao urednik i izdavač ovih mjesečnika, zahvaljujući povremenim kritikama komunističkog režima u Jugoslaviji. Budući da su franjevci trećoreci u Americi, udruženi u crkvenu teritorijalnu jedinicu nazvanu „Komesarijat", bili mecene, financijski omogućujući i podupirući određene projekte koje Provincija nije bila u stanju financirati, u radu se daje uvid u američku potporu jednom od najvećih dostignuća franjevaca trećoredaca u Rimu, a to je dobivanje dopuštenja za provincijski Kolegij „pro Oriente Slavo“ ili „Glagoljaški dom Parčićc. U trećem dijelu rada autor se pozabavio prikazom trećoredske kuće u Washingtonu, koja je prvenstveno kupljena kako bi postala sjemenište, ali je početkom 1980-ih poslužila kao okosnica za Hrvatsku katoličku misiju. U radu se daje prikaz prvih deset godina djelovanja Misije u Washingtonu, od pastoralnih, kulturnih i socijalnih aktivnosti, pa do aktivnosti povezanih s uspostavom slobodne Hrvatske. 


\section{Kratak uvod o odlasku hrvatskih franjevaca trećoredaca glagoljaša u Ameriku}

Franjevci su trećoreci glagoljaši od svojih najranijih početaka druge polovicne trinaestog stoljeća pa sve do trećeg desetljeća dvadesetog stoljeća (1925.) djelovali u Hrvatskom primorju, Dalmaciji i Istri. Tek u prvoj polovini dvadesetoga stoljeća dolaze u kontinentalni dio Hrvatske, u grad Zagreb. Ideju o dolasku franjevaca trećoredaca u Zagreb podržavao je krčki biskup Anton Mahnić, koji je godinu dana prije smrti (1919.), prema svjedočenju fra Ignacija Radića ${ }^{1}$, rekao: „Pođite, pođite u Zagreb. Vi možete ondje s glagoljicom u svetim obredima donijeti velikih koristi Crkvi i narodu našem". Otada se među fratrima razrađuje ta ideja, da bi do njezine realizacije došlo 1922., kad su franjevci trećoreci prihvatili ideju Svetozara Ritiga o osnivanju samostana u Zagrebu. Svetozar Ritig, koji je bio župnik Župe sv. Marka u Zagrebu, nakon pristanka fratara već je sljedeće godine, 1923., poklonio crkvu sv. Franje Ksaverskoga s okolnim zemljištem franjevcima trećorecima. ${ }^{2}$ Fratri pod vodstvom provincijala fra Bone Zeca prodaju pozamašan dio zemljišta na Glavotoku za potrebe gradnje samostana na Ksaveru. U tom je kontekstu Provinciji trebalo dosta sredstava za novi samostan. Stoga je na provincijskom Kapitulu franjevaca trećoredaca 1925. zaključeno da će se izvidjeti mogućnost slanja nekoga fratra u Ameriku i zbog materijalnih potreba, a isto tako da se pođe za našim iseljenicima, čiji je broj bio velik iz Dalmacije i s otoka. ${ }^{3}$ Očito je ta ideja realizirana u osobi fra Stanka Dujmovića, koji dolazi u Ameriku 1926., u Pittsburg, u dobi od 60 godina. Naime, fra Stanko Dujmović od 1907. do 1910. bio je u Americi ${ }^{4}$, u gradiću Spaldingu (Nebraska), kao izaslanik Generala franjevaca trećoredaca te je osnovao danas najbrojniju američku Provinciju franjevaca trećoredaca. ${ }^{5}$ Budući da je boravio u Generalnoj kuriji franjevaca trećoredaca u Rimu sve do 1920., neko je vrijeme bio u Americi; drugi put 1913., kada je u Johnstownu (Pennsylvania) tijekom ljetnih mjeseci zamjenjivao hrvatskog župnika Mirka Kajića.

U svakom slučaju, povijest djelovanja hrvatskih franjevaca trećoredaca glagoljaša u Sjedinjenim američkim državama počinje s njime. Ta povijest i nije tako

\section{RUNJE 2007: 70.}

2 Isto: 71. P. Runje citira članak: BADURINA 1998.

3 U Arhivu samostana sv. Marije na Glavotoku, Spisi 3 (1901. - 1930.). U Zapisniku provincijske kongregacije iz kolovoza 1925. stoji: „Nastojat će se poslati jednog časnog oca u Ameriku da skuplja milostinju za potrebe redodržave i da pripravlja tlo za eventualni otvor jedne naše redovničke kuće na onim stranama“.

4 Vidi: Fra Stanko Dujmović, Knjiga Uspomena II. iz 1906. Dnevnik fra Stanka Dujmovića nalazi se u Arhivu Provincije franjevaca trećoredaca u Zagrebu.

5 Dnevnik koji je fra Stanko Dujmović vodio o svom putovanju i djelovanju u Americi, Svezak II, 1906., preveden je na engleski i darovan Provinciji Presvetog Srca Isusova sa sjedištem u Lorettu, PA, 2007. 
Ilija Živković - Pastoralna, socijalna, kulturna i politička djelatnost franjevaca trećoredaca...

slučajna, kako se u prvi mah čini. Naime, usred teške ekonomske situacije između dvaju ratova, don Joso Sorić iz Preka na otoku Ugljanu, koji je bio župnik u hrvatskoj Župi sv. Nikole u Millvaleu, u predgrađu Pittsburgha, savjetuje tadašnjeg provincijala fra Bona Zeca da pošalje jednog redovnika u Ameriku. Budući da je fra Stanko Dujmović vjerojatno bio jedini hrvatski franjevac trećoredac koji je znao engleski jezik, njega odabiru kao dobrog poznavatelja ne samo jezika, nego i prilika u Americi. ${ }^{6}$ Fra Stanko dolazi u Pittsburgh 21. travnja 1926. i nastanjuje se kod don Jose Sorića u Župi sv. Nikole u Millvaleu. Ta se župa odvojila od prve hrvatske Župe sv. Nikole u sjevernom dijelu Pittsburgha 1899. ${ }^{7}$ Početkom lipnja odlazi k župniku prve hrvatske crkve i župe u sjevernom dijelu Pittsburgha, vlč. Ferdinandu Dujiću. ${ }^{8}$ Istoga je dana župnik Dujić otputovao za Hrvatsku, povjerivši fra Stanku da se ne kani vratiti natrag. Budući da se župnik nije vraćao, biskup je fra Stanka postavio za v. d. župnika te vrlo brzo i za samog župnika. S obzirom na to da je fra Stanko već bio u šezdesetoj godini života, zatražio je od biskupa dopuštenje za traženje pomoći mladih redovnika iz Hrvatske. Biskup je to dopustio i već u veljači 1927. iz Hrvatske dolazi fra Albert Žagar. Žagar odmah dobiva jurisdikciju jer u Župi sv. Nikole u Pittsburghu nije bilo potrebno znanje engleskog jezika. Također je imenovan pomoćnikom fra Stanka Dujmovića. Čini se da je župa bila dosta zapuštena, i materijalno i duhovno. Dvojica trećoredaca, iako bez nekoga značajnog pastoralnog iskustva, svojski se zalažu na pastoralnom planu, tako da već u svibnju dolazi biskup za krizmu te se jako pohvalno izražava o fra Dujmoviću i njegovu pomoćniku. I župljani traže da se župa dade ovoj dvojici i da se fra Žagara postavi za kapelana, što je biskup vrlo brzo i napravio. Naime, radilo se o velikoj župi. Prva hrvatska župa u Americi imala je oko 1.000 članova ili oko sto obitelji. ${ }^{9}$ U travnju 1928., na inzistiranje fra Dujmovića, fra

6 Podrobnije o ocu Stanku Dujmoviću piše fra Nikola Gregov (GREGOV 1965: 37-40; 66-73).

7 Prva hrvatska crkva i župa bila je u sjevernom dijelu Pittsburgha. Crkvena slavlja odvijala su se u preuređenoj kući od 27. siječnja 1895. pa do dolaska Franje Glojnarića 26. prosinca 1898. On je inicirao ideju da se kupi novo zemljište za crkvu. Tako „kupiše zemljište u Millvalu, što dovede do žestokih svađi i rascjepa. Vlč. Glojnarić nakon godinu dana napušta župu sv. Nikole i odlazi na novokupljeno zemljište na području Millvela i tu gradi crkvu isto tako posvećenu Sv. Nikoli“. Spomen knjiga zlatnog jubileja Prve Hrvatske Rimokatoličke Župe sv. Nikole 1944: 20.

8 Fra Nikola Gregov piše da je dolaskom u Ameriku fra Dujmović dobio ponudu američkih franjevaca trećoredaca da bude profesor na njihovoj teologiji u Lorettu. Dujmović je to odbio jer se nadao da će mu biskup naći unosniji posao, s obzirom na to da je govorio engleski, njemački, talijanski i hrvatski (GREGOV 1965).

9 Stotinu obitelji (oko 1.000 vjernika). To se tumači tako što je u to vrijeme svaka obitelj udomljivala i prehranjivala više odraslih ljudi, čak po trideset i više njih. Naime, najveći broj hrvatskih doseljenika bili su samci, koji su vrebali priliku da dovoljno zarade kako bi mogli iz domovine k sebi pozvati suprugu te su stoga kao samci živjeli u velikim kućanstvima, gdje bi imali krevet i hranu (MAROHNIĆ 1902). 
Žagar imenovan je upraviteljem župe, dok je fra Stanko Dujmović postao njegovim pomoćnikom. Krajem 1929. Provincija franjevaca trećoredaca u Pittsburgh šalje fra Dobroslava Sorića, koji je već početkom prosinca na inzistiranje fra Dujmovića imenovan pomoćnikom fra Žagaru u Župi sv. Nikole u Pittsburghu. s namjerom vraćanja svojoj kući, fra Dujmović se pošao pozdraviti s biskupom prije polaska za Hrvatsku, kad ga je ovaj zamolio da nakratko preuzme upravu novoosnovane župe u Ambridgeu nedaleko od Pittsbrugha. Teška srca prihvaća tu dužnost, na kojoj ostaje oko devet mjeseci (do kolovoza 1930.), a onda se vraća u Pittsburgh. Na njegovo mjesto u Ambridge odlazi fra Dobroslav Sorić. Vrlo brzo, polovinom siječnja 1931., naglo je ostala ispražnjena susjedna Župa sv. Nikole u Millvaleu. Biskup ubrzo i tu župu nudi fra Stanku Dujmoviću. Fra Stanko iz osobnih razloga ${ }^{10}$ odbija biti župnikom, ali predlaže da se na tu funciju postavi fra Alberta Žagara, što biskup i prihvaća. Na mjesto upravitelja Župe sv. Nikole u Pittsburghu iz Ambridgea dolazi fra Dobroslav Sorić, kome fra Stanko postaje pomoćnikom. Fra Stanko Dujmović u veljači 1931. teško se razbolio te se nakon operacije odlučio na povratak u domovinu, što se i dogodilo nakon oporavka od bolesti u kolovozu 1931. Vraća se u Zagreb te u svoj dnevnik zapisuje: „Lijepo me je iznenadio novi samostan u Zagrebu, plod mojih trudova u Americi... Bog dragi je blagoslovio u svakom pogledu naše djelovanje u Americi“" ${ }^{11}$ Nakon povratka iz Amerike odlazi u Herceg Novi, gdje umire 1940. Njegovi se posmrtni ostaci i dalje nalaze na mjesnom groblju u Herceg Novom. ${ }^{12}$

\section{Pastoralna djelatnost franjevaca trećoredaca u Americi}

Krajem 1920-ih i početkom 1930-ih godina hrvatski franjevci trećoreci dobivaju tri župe u Pittsburghu i okolici, na kojima ostaju do kraja dvadesetoga stoljeća. Dvije su povjerene župe u predgrađu Pittsburgha, a posvećene su sv. Nikoli. Međusobna je udaljenost svega nekoliko kilometara. To su ujedno i dvije prve župe u Americi. Treća je župa nedaleko od Pittsburgha u McKeesportu, a povjerena je hrvatskim franjevcima trećorecima 1936. Budući da su franjevci

10 GREGOV 1965.

11 Na istome mjestu. Izgleda da je on, zajedno s fra Žagarom i fra Sorićem, uistinu pridinio značajnim novčanim iznosom za gradnju Ksavera. Naime, u svom izvješću o troškovima za gradnju Ksavera do 1932. tadašnji provincijal Ignacije Mašina ističe da su braća iz Amerike donirala 480.000 dinara. O kakvom se iznosu radi teško je danas reći, ali usporedbe radi, nadbiskup Bauer prilikom otvaranja samostana sv. Franje Ksaverskog 1924. franjevcima poklanja svotu od 2.000 dinara (RUNJE 2007: 71).

12 Na Generalnom Kapitulu franjevaca trećoredaca, održanom u Gamingu (Austrija) u svibnju 2013., novoizabrani general Reda fra Nicolas Polinovsky izrazio je želju da bi njegova matična provincija Presvetog Srca Isusova rado prenijela posmrtne ostatke fra Stanka Dujmovića, kao utemeljitelja njihove Provincije, u Sjedinjene Američke Države. 
trećoreci dobili tri župe, Provincija s vremenom šalje sve više fratara, stoga 1940. osniva Komesarijat, kojemu je prvi komesar bio fra Albert Žagar. Nakon njega tu službu obavlja fra Dobroslav Sorić, a od 1967. fra Romildo Hrboka te od 1976. pa do 2004. fra Gabrijel Badurina. Kroz taj je Komesarijat sveukupno prošlo 19 fratara. ${ }^{13}$ Komesarijat nikada nije ukinut službenim aktom. Međutim, nakon što je i posljednja hrvatska župa u Americi 2004. ukinuta, na američkom tlu ostala su samo dvojica franjevaca trećoredaca: fra Romildo Hrboka, koji je želio ostati u Americi do smrti, i fra Gabrijel Badurina, koji je dobio mjesto kapelana u jednoj američkoj župi u blizini Pittsburgha te koji je želio ostati u blizini fra Hrboke za njegova života. Nakon nešto više od godine dana, poslije smrti fra Romilda Hrboke (2007.) posljednji član Komesarijata, fra Gabrijel Badurina, vraća se u Hrvatsku 2011. Svojevrsna deklaracija prestanka Komesarijata možda bi se mogla očitati i preko punomoći, koju je provincijal fra Ivan Paponja odmah nakon smrti fra Romilda Hrboke u Pittsburghu 2007. napisao fra Iliji Živkoviću 25. rujna iste godine, kojom ga se pred američkim vlastima ovlašćuje da zastupa sve radnje oko financijskih poslova povezanih s Komesarijatom franjevaca trećoredaca u SAD-u.

\section{1. Župa sv. Nikole u sjevernom dijelu Pittsburgha (North Side)}

Dvije godine nakon dolaska fra Stanka Dujmovića za upravitelja Župe sv. Nikole u Pittsburghu (North Side) za župnika je 1928. imenovan fra Albert Žagar, franjevac trećoredac, podrijetlom Slovenac, rođen u Osilnici blizu Kočevja 1893. Taj je mladi i energičan franjevac, uz svoga kolegu fra Dobroslava Sorića, bio arhitekt djelovanja franjevaca trećoredaca u Americi. U roku od triju godina župnikovanja isplaćuje poprilično velik dug Župe sv. Nikole, koji je iznosio oko 63.000 američkih dolara. Revno se baca na pastoralan posao, o kojemu kroničari pjevaju hvalospjeve. ${ }^{14}$ Osobno je obilazio vjernike, podizao duh i duhovno probudio župu. Osnovao je i aktivirao neka zamrla katolička društva. Posebno je uspješan bio u osnivanju djevojačkog društva Marijine Kongregacije, iz kojeg su mnoge djevojke otišle za redovnice. Vrlo aktivno radi na otvaranju katoličke škole u župi. U tu svrhu kupuje dvije stare kuće. Međutim, biskup ga premješta u Millvale i ne uspijeva realizirati svoj projekt. To čini fra Dobroslav Sorić, koji dolazi na mjesto župnika u veljači 1931. U nastupnoj propovijedi kao novi župnik ističe dva prioriteta: osnivanje katoličke škole u što kraćem roku, oživljavanje postojećih katoličkih društava te osnivanje novih. ${ }^{15}$

\footnotetext{
13 Ti su fratri: Stanko Dujmović, Albert Žagar, Dobroslav Sorić, Šime Vladović, Ante Nižić, Frane Karavanić, Marijan Sorić, Sebastijan Lončar, Mirko Usmijani, Teodor Badurina, Romildo Hrboka, Danijel Valčić, Bruno Nižić, Ivo Marcelić, Gabrijel Badurina, Petar Runje, Ivan Badurina, Melkior Mašina i Ilija Živković.

14 Spomen knjiga zlatnog jubileja 50-godišnjice 1944: 46-50.

15 Isto: 53.
} 
Nakon pažljivog odabiranja mjesta pogodnog za izgradnju škole, fra Dobroslav Sorić, zajedno sa svojim župnim vijećem, odlučio je da se kupi gradska pučka škola za 41.000 dolara. Nakon dobivanja kredita u banci Workingmans Savings 18. kolovoza 1931. ${ }^{16}$, škola je kupljena, a fra Dobroslav Sorić poziva časne sestre, kojima on i župa grade veleban samostan na terenu koji je kupio prethodni župnik fra Albert Žagar. Već 6. rujna 1931. svečano se slavi 30. obljetnica crkve sv. Nikole te blagoslov i otvaranje nove hrvatske katoličke škole i samostana časnih sestara. Nova je škola već u samom početku imala 240 učenika. ${ }^{17}$ Fra Sorić pozvao je časne sestre franjevke iz Lemonta (Illinois). To su bile franjevke trećoredice slovenskog i hrvatskog podrijetla. U novi samostan doselilo se 8 sestara, koje su bile izvanredno dobro prihvaćene.

Fra Dobroslav Sorić, dosljedan planu koji je najavio, svesrdno radi na obnovi postojećih društava u župi i osnivanju novih. Obnovljena je, gotovo već zamrla, Bratovština kršćanskih majki, koja dobiva svoja pravila, odnosno Statut. Isto tako obnavlja društvo Imena Isusova, koje je bilo jako popularno u Americi, a čiji je glavni cilj bio pristupiti ispovijedi i svetoj pričesti barem jednom mjesečno. To je društvo u Župi sv. Nikole osnovano još 1910., ali je s vremenom zamrlo. Uz ogromne napore fra Sorića za oživljavanjem tog društva, maksimalan broj članova bio je 50, što se tumači tako da su Hrvati teže prihvaćali običaje o pristupanju svetim sakramentima češće nego dvaput godišnje (o Uskrsu i Božiću). Godine 1934. fra Sorić osniva i ogranak društva Imena Isusova za mladiće.

U župi je kanonski osnovana Marijina Kongregacija za djevojke, koja ima tri ogranka: Marijinu djecu (za djevojčice) i za djevojke te za dječake. U ovu se Kongregaciju na početku javlja 26 djevojčica i 81 djevojka te 19 dječaka. Također, za žene i udovice osniva bratovštinu Kršćanskih majki. Za djecu do desete godine osniva društvo Počasne straže Presvetog Srca Isusova. Fra Dobroslav Sorić također je pomogao da „Liceum“, kao mjesto okupljanja i zabave mladih, opet zaživi tako što je otplatio dug potonjega te ga uvrstio kao vlasništvo crkve sv. Nikole i time mu ponovno udahnuo dušu.

Fra Dobroslav osnovao je i Društvo za proširenje svete vjere. Također je postojalo i Društvo sv. Nikole Hrvatske katoličke zajednice, Društvo svete Tereze od Malog Isusa, kao i Društvo Svete Obitelji. Ta su tri društva pripadala ograncima Hrvatske katoličke zajednice, ali je župa bila koordinatorica njihovih aktivnosti. Župa sv. Nikole u Pittsburghu za vrijeme Dobroslava Sorića imala je četiri crkvena zbora (zbor djevojaka, zbor školske djece, muški zbor i „Comerical High School“ zbor).

U spomen-knjizi 50-godišnjice Župe sv. Nikole piše: „Da se izbjegne svim možebitnim nesporazumima i da sve katolička vjerska društva u župi uzmognu

\footnotetext{
Isto: 55

17 Isto: 67-73, gdje je donesen popis imena i prezimena svih učenika od prvog do osmog razreda.
} 
Ilija Živković - Pastoralna, socijalna, kulturna i politička djelatnost franjevaca trećoredaca...

jednostavnije, složenije, rame uz rame raditi za jedan isti cilj, zasnova župnik Rev. D. Sorić središnjicu za sa katolička vjerska društva ili centralu“. ${ }^{18}$ Svako je društvo, naime, imenovalo petero svojih članova, koji su služili kao delegati centrale. Centrala je dobila svoj pravilnik u listopadu 1932. te je otada počela funkcionirati. U početku je imala dva pododbora: pododbor za širenje dobre štampe te onaj za prehranu siromašne djece i pomoć siromašnim obiteljima. Ne zna se zašto je ta centrala s radom prestala već u lipnju 1933., iako je njezin rad bio više nego očit. ${ }^{19}$

Fra Sorić pokreće i mjesečnik Vjesnik s informacijama o događajima u župi, koji na 16 stranica redovito počinje izlaziti svakog mjeseca, od ožujka 1932. do svibnja 1933. Autor ovoga članka nije bio u stanju pronaći razloge obustave izlaženja Vjesnika. Fra Sorić također uvodi pobožnosti u čast sv. Antunu, sv. Tereziji od Maloga Isusa, Srcu Isusovu (svakoga petka) te sv. Franji Asiškome. Uz sve župne i pobožne aktivnosti, Dobroslav Sorić u svibnju 1943. odlučuje se na izdavanje časopisa Ave Marija, po kojemu je vjerojatno postao poznat širom Sjedinjenih Američkih Država.

Pored čitavog pastoralnog rada, uredio je i samu crkvu - gotovo svu unutrašnjost, oltare i propovjedaonicu, a pod je obložio i ukrasio najboljim talijanskim mramorom. Izgradio je i svetište i špilju Gospe Lurdske na brijegu između crkve i župnog stana. Samo za pripremu terena trebalo je premjestiti 600 tona zemljišta. Također je preuredio i obnovio župni stan. Zbog silno velikih aktivnosti fra Dobroslava Sorića 1947. udarila je „moždana kap“. Zbog toga je 1948. premješten u Župu Presvetog Srca Isusova u McKeesportu.

Nakon fra Dobroslava Sorića u tu župu dolaze sljedeći franjevci trećoreci: fra Sebastijan Lončar, fra Marijan Sorić, fra Danijel Valčić, fra Bruno Nižić i fra Ivo Marcelić. Posljednji je župnik bio fra Grgo Sikirić. ${ }^{20}$ Svi su oni više ili manje održavali zacrtane programe fra Dobroslava Sorića te održavali crkvu, ali bez

Spomen knjiga zlatnog jubileja 50-godišnjice 1944: 102.

19 „Pododbor za širenje dobre štampe je u roku od tri mjeseca otvorio župsku knjižnicu i čitaonicu u kojoj je bilo više od petsto knjiga što na hrvatskom, što na engleskom", a na velikom se stolu znalo naći i dvadeset do trideset raznih novina i glasnika. Pododbor je za prehranu siromašne djece od listopada 1932. pa do lipnja 1933. ,podijelio preko 10.000 besplatnih obroka koji su obuhvaćali $800 \mathrm{~kg}$ kruha, $150 \mathrm{~kg}$ masti, 1200 konzervi juhe od rajčice, preko 900 limenki graha, preko 400 kg mesa, 800 limenki graška, preko stotinu kutija marmelade i 600 galona mlijeka (2200 litara)“ (Spomen knjiga zlatnog jubileja 50-godišnjice 1944: 105).

U Arhivu Komesarijata franjevaca trećoredaca (Odra, Zagreb) nalazimo popis trećoredaca koji su bili župnici Župe sv. Nikole u North Sideu u Pittsburghu. Fra Stanko Dujmović bio je župnik od 5. siječnja 1926. do 19. ožujka 1928.; fra Albert Žagar od 19. ožujka 1926. do 12. veljače 1931.; fra Dobroslav (Boniface) Sorić od 12. veljače 1931. do 18. siječnja 1948.; fra Sebastijan Lončar od 18. siječnja 1948. do 5. veljače 1956.; fra Marijan Sorić od 5. veljače 1956. do 10. veljače 1963.; fra Danijel Valčić od 10. veljače 1963. do 13. travnja 1964.; fra Bruno Nižić od 13. travnja 1964. do 10. ožujka 1968.; fra Ivo Marcelić od 10.ožujka 1968. do 12. veljače 1971.; fra Marijan Sorić od 12. veljače 1971. do 22. siječnja 1978.; fra Grgo Sikirić od 22. siječnja 1978 do 2000. te fra Gabrijel Badurina kao župnik personalne župe od 2000. do 2002. 
velikih pastoralnih, duhovnih i kulturnih iskoraka. S vremenom je ta župa sve više izumirala, posebno zato što su se potomci Hrvata selili na periferiju Pittsburgha. Po svoj prilici najaktivniji župnik iza fra Dobroslava Sorića bio je fra Grgo Sikirić, koji se svim snagama borio za opstanak svoje župe. Međutim, njegovi planovi o očuvanju kulturne baštine Hrvata nisu naišli na podršku ni biskupije ni vlastite subraće franjevaca, koji su vodili crkvu sv. Nikole u Millvaleu. Stoga je biskup čekao priliku da se proslavi 100. obljetnica prve hrvatske crkve te je iste, 1994., ukinuo tu župu. Župa sv. Nikole u North Sideu postala je personalna župa, pripojena župi sv. Nikole u Millvaleu. Posljednji župnik, fra Grgo Sikirić, umirovljen je čim je navršio 75 godina, a u Hrvatsku se vratio H 20. svibnja 2000.

Crkva je sv. Nikole u potpunosti zatvorena 2002. Župljani i mnogi Hrvati iz Pittsburgha i okolice deset godina borili su se kako bi crkvu spasili od rušenja. Bilo je prijedloga da se u njoj napravi etnički muzej. Čak je i poglavarstvo Pittsburgha podržalo tu ideju. Biskupiji se nudilo 350.000 USD za prepuštanje crkve gradu, ali je biskupija odbila sve prijedloge. U siječnju 2013. godine prva hrvatska crkva i prva hrvatska župa u Americi srušena je do temelja.

\section{2. Župa sv. Nikole u Millvaleu}

Riječ je o drugoj hrvatskoj župi u Americi, osnovanoj 1900. nakon ozbiljne podjele među župljanima prve hrvatske crkve sv. Nikole u Pittsburghu (North Side). U tu je župu 1920. iz Hrvatske došao vlč. Josip Sorić, rodom iz Preka, očito dobar prijatelj franjevaca trećoredaca, koji je i dao ideju trećoredskom provincijalu da svoje fratre počne slati u Ameriku. Početkom 1931. vlč. Sorić biva premješten, a na njegovo mjesto dolazi fra Albert Žagar.

Otac Žagar, kojeg su inače zvali stručnjakom za otplaćivanje kredita ${ }^{21}$, našao je župu u ogromnim dugovima. Naime, prije nego što je imenovan župnikom u Millvaleu župna crkva, koja je bila izgrađena od drveta, izgorjela je do temelja. Stoga je prethodnik fra Žagara, vlč. Joso Sorić, počeo graditi novu crkvu od cigle. $U$ to je vrijeme nastupila i ogromna ekonomska kriza, poznata pod imenom „Velika depresija“, te je dug zato naglo narastao. Kad je Albert Žagar imenovan Župnikom, dug za gradnju crkve, škole i svih poslova u koje se ubacio prethodnik iznosio je, 98.298,49 USD. ${ }^{22}$ Stoga je fra Žagar u početku prosjačio, hodajući od kuće do kuće, ne bi li uspio štogod prikupiti. S vremenom je zadobio povjerenje ljudi, koji su počeli obilnije pomagati. U roku od 12 godina fra Žagar isplatio je sav dug i svečano spalio zadužnicu (mortgage) na banketu 6. prosinca 1944. ${ }^{23}$

21 Tako ga naziva fra Dobroslav Sorić u svom prikazu rada i djelovanja Župe sv. Nikole u Millvaleu (SORIĆ 1967: 5).

22 Spomen knjiga 50-godišnjici 1944: 40.

23 Spaljivanje zadužnice bilo je svečan čin, za koji su Hrvati imali i pjesmu pod naslovom „Nek se pali mortgage kleti“ (Spomen knjiga zlatnog jubileja 1944: 49). 
Odmah nakon dolaska fra Žagar daje se na uređenje crkve iznutra. Dolazi na ideju o pozivanju hrvatskog slikara Maksimilijana Vanke kako bi mu oslikao unutrašnjost crkve. Tim je činom izašao iz okvira običnog župnika i svoju crkvu pretvorio u umjetničko blago, koje nadilazi okvire crkve emigranata. Fra Žagar na svojoj je župi već imao školu i časne sestre franjevke. Njima 1954. gradi velik i prostran samostan s ogromnim parkiralištem. Dvije godine kasnije gradi novi župni stan.

Kad je fra Žagar došao u župu, škola je imala 80 učenika. Stoga se već 1936. odlučuje na kupnju školskog autobusa te je već sljedeće godine u školi bilo 260 djece. Godine 1962. fra Žagar je odlučio izgraditi novu školu, koja je funkcionirala sve do njezina zatvaranja 1986. Za svoga župnikovanja kupio je novo groblje.

Fra Žagar također je puno radio na duhovnom planu. Više ili manje osnovao je iste bratovštine koje je imao u Župi sv. Nikole u Pittsburghu. Aktivno radi s Marijinom Kongregacijom, koja isto tako ima tri odjela (za djevojčice, djevojke i mladiće). Osim toga, osniva Društvo za proširenje svete vjere te Društvo svete Obitelji.

U mirovinu odlazi 1966., ali i dalje ostaje u župi sv. Nikole u Millvaleu sve do svoje smrti 28. veljače 1968. Zamjenjuje ga fra Romildo Hrboka, koji u toj župi ostaje do umirovljenja 1999., a njega nasljeđuje fra Gabrijel Badurina, koji ondje ostaje do 2004., kad franjevcima trećorecima pitsburški biskup oduzima tu župu jer u tom dijelu Millvalea gotovo da više i nema stanovnika, niti vjernika. U spomenutoj su župi, osim nabrojenih župnika, kao kapelani djelovali sljedeći franjevci trećoreci: fra Ante Nižić, fra Sebastijan Lončar, fra Mirko Usmijani i fra Marijan Sorić. Nakon fra Žagara u župi se više ništa značajno nije događalo. Fra Romildo Hrboka održavao je i pomalo gasio ono što je stvarao veliki karizmatik i radnik fra Žagar. Ta je crkva sada filijala Župe sv. Ante iz Millvalea te se u njoj povremeno održava misa.

\section{3. Župa Presvetog Srca Isusova u McKeesportu}

Hrvati su u McKeesportu 1906. za 6.000 dolara kupili crkvu Prve švedske baptističke zajednice te su je preuredili i dali joj ime Presvetog Srca Isusova. Ubrzo su kupili i župnu kuću, doveli časne sestre te otvorili školu. Godine 1926. prodali su crkvu te napravili novu veliku školu, gdje su održavali i vjerske obrede. Župa je bila dosta aktivna sve dok 1934. vrlo aktivan župnik, Slovenac vlč. Matej Kebe, nije otišao u slovensku župu u Pittsburghu. Nakon toga tijekom dviju godina izmjenjuju se dvojica župnika, koja se ne snalaze, te biskup odluči župu ponuditi hrvatskim franjevcima trećorecima. Tako 2. siječnja 1936. u tu župu dolazi fra Franjo Karavanić, koji nasljeđuje dug od 88.302,79 USD. ${ }^{24}$ Sama je

${ }_{24}$ Sacred Heart Parish 50-th Golden Jubilee and Solemn Dedication of the New Church 1956. (knjiga nema obilježenih stranica) 
župa bila „materijalno ugrožena, a narod gospodarski iscrpljen i nezadovoljan“ “. ${ }^{25}$ Fra Karavanić napornim radom tijekom deset godina uspijeva otplatiti ogroman dug. Međutim, zbog prevelikih aktivnosti ozbiljnije obolijeva te odlazi u samostan Loretto k američkim franjevcima trećorecima na oporavak tijekom 1946. i 1947. Zamjenjuje ga fra Marijan Sorić sve do polovine siječnja 1948., kad za župnika iz Pittsburgha dolazi fra Dobroslav Sorić. Kada se prvi put predstavio svojim vjernicima, fra Dobroslav rekao je: „Bog mi je dao milost, da sam sa hrvatskim narodom u Pittsburghu proslavio 50 godišnjicu one prve hrvatske crkve u Americi pak se nadam, da će mi dobri Bog dati milost da proslavim s vama u McKeesportu 50. godišnjicu vaše i sada moje hrvatske župe. Ali proslavu zlatnog pira ove župe ne smijemo proslaviti ovdje u školskoj zgradi na trećem katu, već to moramo obaviti u lijepoj novoj crkvi i to godine 1956., kada ova župa bude slavila svoj zlatni jubilej“. ${ }^{26}$ Poduzetni je fra Dobroslav Sorić odmah utemeljio fond pod nazivom „Dollar or more Sunday Club“. U početku je taj klub brojio nekoliko članova, ali prema pisanju Dobroslava Sorića, 1956. u župi je bila sramota ne biti članom toga kluba. Nova, velebna crkva doista je blagoslovljena 27. svibnja 1956., kako je Dobroslav Sorić i obećao. Crkva i župna kuća naslonjena na nju koštala je 320.000 USD, a sav taj trošak isplaćen je u sljedećim dvjema godinama. Fra Dobroslav neumorno radi u pastoralu, ali se sve više angažira i na kulturnom planu. Kupuje tiskaru i u župi izdaje mjesečnike Ave Maria i Immaculate Conception. Zbog politike, a službeno zbog bolesti, smjenjuje ga se kao župnika 1964. te na njegovo mjesto dolazi fra Marijan Sorić. Nakon njega župnikom je 1970. imenovan fra Gabijel Badurina. Budući da je čelična industrija u okolici Pittsburgha počela propadati, već sredinom 1970-ih počinju se gasiti čeličane u McKeesportu, što uzrokuje i iseljavanje mlađeg stanovništva. U župi se gasi škola 1976. Iako je Župa Presvetog Srca Isusova bila najaktivnija i po broju vjernika najbrojnija, biskupija ju je odlučila ugasiti 1994., a posljednji župnik fra Gabrijel Badurina odlazi u Hrvatsku katoličku misiju sv. Blaža u Washingtonu. Kapelani u McKeesportu bili su: fra Ante Nižić, fra Marijan Sorić i fra Dobroslav Sorić.

\section{Kulturna, prosvjetiteljska i politička ostvarenja Komesarijata franjevaca trećoredaca u Americi. Vankine slike u crkvi sv. Nikole u Millvaleu}

Otac je Albert Žagar početkom 1936., uz pomoć župljanina Luisa Adamića ${ }^{27}$, pozvao Maksimilijana Vanku, hrvatskog slikara, da oslika tek dovršenu crkvu sv. Nikole u Millvaleu u predgrađu Pittsburgha. Gospodin Vanka, koji je diplomirao

\footnotetext{
$25 \mathrm{Na}$ istome mjestu.

$26 \mathrm{Na}$ istome mjestu.

27 DOMENCIC 2000.
} 
Ilija Živković - Pastoralna, socijalna, kulturna i politička djelatnost franjevaca trećoredaca...

u Belgiji te u Bruxellesu dobio prvu nagradu za portrete seljaka u Hrvatskoj, prihvatio je tu ponudu, koja je u njegovu životu predstavljala prekretnicu i plasirala ga među najpoznatije hrvatske slikare u Americi i izvan domovine. Fra Žagar dao mu je gotovo potpunu slobodu umjetničkog izražavanja, s time da je tražio kako određen broj slika mora imati religiozan sadržaj. Gospodinu je Vanki također rečeno da bi zidovi crkve trebali biti oslikani u roku od dvaju mjeseca. Tako je Vanka 9. travnja 1937. započeo s prvom freskom (muralom) iznad glavnog oltara na površini od $108 \mathrm{~m}^{2}$. Tema je freske Gospa s djetetom Isusom.

Zanimljivi su tipični hrvatski detalji: Isus u haljinici s hrvatskim ornamentima u rukama drži klasje žita i grozd. Na toj ogromnoj slici Vanka je ispod Gospe, a također i s obiju strana ukomponirao čitavu povijest hrvatskih useljenika $\mathrm{u}$ Americi. S lijeve su strane oslikane prekrasne scene hrvatskoga krajolika, iz kojeg su došli Hrvati u Pittsburgh (uključujući i religioznu tradiciju pozdrava Gospi u podne), a s desne je oslikana sudbina radnika u rudnicima i tvornicama Pittsburgha i okolice.

U tom prvom razdoblju do 9. lipnja 1937. Vanka je oslikao desetak murala, koji po svoj prilici predstavljaju najbolje ispričanu priču o sudbini hrvatskih imigranata u Americi između dvaju svjetskih ratova. Tom pričom također dominiraju dvije teme: pobožnost Hrvata u Americi i smrt Hrvata u Pennsylvaniji. Mnogi poznavatelji umjetnosti ističu ${ }^{28}$ da su impresivne Vankine slike bile pod utjecajem meksičkih zidnih slikara, poput Diega Rivere ili Josea Clementea Orozcoa. Najimpresivnije su slike posvećene žalosnim majkama. Na jednoj majka u Hrvatskoj oplakuje sina koji je poginuo za Austriju u Prvom svjetskom ratu (kao žrtva politike), a na drugoj majka također oplakuje sina poginulog u rudnicima Pittsburgha (kao žrtva industrije). ${ }^{29}$

Vanka ponovno dolazi oslikati preostali dio crkve, uglavnom strop i prostor ispod kora 1941. U tom razdoblju prevladavaju slike socijalnih nepravdi te se naslućuju strahovi od posljedica Drugog svjetskog rata i briga za sudbinu hrvatskog naroda. Najveći dio stropa oslikan je biblijskim i religioznim likovima (Uznesenje Kristovo, Mojsije, sv. Franjo, sv. Klara, anđeli itd.). Posebno su impresivne dvije slike, koje naglašavaju socijalnu nepravdu: slika hrvatske siromašne obitelji, koja se priprema za oskudan ručak, nasuprot bogatom industrijalcu, koji čita izvješće s burze, s tipičnim cilindrom koji podsjeća na „Unclea Sama“, čime ostavlja dojam da je neosjetljiv na bilo čije potrebe. Brigu za sudbinu hrvatskoga naroda Vanka je izrazio slikom pod nazivom „Majka Hrvatska“, koja je okovana lancima fašizma.

Te su freske početkom 1940-ih bile česta tema američkog tiska, časopisa, a i umjetničkih revija. Kritičari su vrlo povoljno pisali o trećoredskoj crkvi sv.

\footnotetext{
HARRIS 1981.

29 Tu je sliku potaknuo istinit događaj nesreće u rudniku na području Johnstowna, u kojoj je jedna hrvatska obitelj izgubila četvoricu sinova.
} 
Nikole, koja ima ,jednu od najboljih zbirki murala (fresaka) u svijetu“. ${ }^{30}$ Država Pennsylvania i grad Pittsburgh 1980. hrvatsku crkvu sv. Nikole u Millvaleu uvrstili su u nacionalni popis povijesnih mjesta u Americi. Od 1990. registrirano je Društvo za očuvanje freski crkve sv. Nikole u Millvaleu, koje postoji i danas.

\section{1. Časopis Ave Maria i Immaculate Conception}

Fra Dobroslav Sorić počeo je tiskati mjesečnik Ave Maria 1943. na hrvatskom jeziku. Taj je mjesečnik bio namijenjen Hrvatima u Americi koji su slabo ili nikako govorili engleski. Mjesečnik (do čijeg primjerka sve do danas autor ovog članka nije uspio doći) je tijekom Drugog svjetskog rata trebao nadoknaditi nedostatak informacija, pogotovo onih crkvenog karaktera, hrvatskim katolicima u Americi. ${ }^{31}$

Taj je glasnik redovito izlazio svakog mjeseca sve do travnja 1948., kada je od Generala franjevaca trećoredaca stigla zabrana izdavanja mjesečnika Ave Maria. Po svoj je prilici odluka Generala bila uvjetovana politikom, odnosno dolaskom komunista na vlast u Hrvatskoj 1945. Može se pretpostaviti kako su fratri iz Hrvatske strahovali da će se komunističke vlasti obrušiti na njih zbog tog mjesečnika. S druge strane, u Rimu je bio definitor iz Hrvatske i nekadašnji provincijal fra Lovro Hržić, koji je predstavljao vezu između Provincije, Generalata i Komesarijata u Americi. Iako General u svom službenom aktu ${ }^{32}$ navodi dva glavna razloga za obustavu izdavanja mjesečnika Ave Maria - bolest urednika i financijske poteškoće - teško je povjerovati da su to bili pravi razlozi. Iz privatnih pisama fra Dobroslava Sorića vidi se da je bio pun prezira prema komunistima te da se nije ustručavao davati svoje kritike na njihove poteze $\mathrm{u}$ Hrvatskoj. Iz usmenih izvora starijih fratara moglo se čuti da je urednik časopisa fra Dobroslav u Ave Mariji vodio bitku protiv ateističkog komunizma. Očito je da se i članovima Komesarijata na indirektan način predlagalo da glasuju protiv izdavanja mjesečnika, odnosno da podrže Generalovu odredbu. U svom pismu članovima Komesarijata fra Dobroslav Sorić navodi razloge i prigovore na račun mjesečnika, koji su bili sljedeći: mali opseg mjesečnika, nedostatak sadržaja, nepotrebnost zbog velikog broja drugih listova, izumiranje Hrvata u Americi i sl. ${ }^{33}$

30 Pitsburški Sun-Telegraph nazvao je Vankine umjetnine u crkvi Sv. Nikole „world famous“, a Pittsburgh Press „The best church-murals in America“ (ŽAGAR 1950: 57).

31 Fra Dobroslav Sorić u Vjesniku franjevaca trećoredaca glagoljaša (1967: 31) piše: ,jer nažalost radi velikog svjetskog rata nije naš narod više dobivao bogoljubnih glasnika iz svoje domovine Hrvatske“.

32 Fra Dobroslav Sorić u pismu braći u Komesarijatu u Americi, ručno datiranom Februar - 1951 kao komesar ističe da je „Ave Maria magazin bio ukinut, kako službeni akt. preč. Genaral kaže, radi bolesti urednika i radi financijskih poteškoća oko izdavanja istog magazina“.

33 U svom pismu braći u Komesarijatu, ručno datiranom Februar - 1951. (Arhiv Komesarijata), fra Dobroslav nabraja razloge protiv izdavanja magazina. Na primjedbu da je „naš list vrlo malen“ kaže: „Ima u Americi mnogo manjih magazina nego je bio Ave Maria. Pogledajte list 'Fatima', 
Ilija Živković - Pastoralna, socijalna, kulturna i politička djelatnost franjevaca trećoredaca...

U tom pismu iz veljače 1951. fra Sorić opisuje trenutačnu situaciju te sugerira da braća u Komesarijatu prihvate ponovno pokretanje mjesečnika Ave Maria. Između ostalog, ističe da on kao glavni urednik više nije bolestan te da je uspio pronaći dobrotvore koji će plaćati za tisak i opremu mjesečnika. ${ }^{34}$ Dokazuje da razlozi i prigovori na račun prestanka izlaženja mjesečnika Ave Maria više ne stoje, stoga subraći u Komesarijatu preporučuje donošenje pozitivne odluke kako bi Ave Maria opet počeo izlaziti u svibnju 1951. Iako nemamo dokumente koji bi potvrdili pozitivan stav članova Komesarijata, ipak znamo da je Ave Maria opet počeo izlaziti i to u siječnju 1952., nakon što je i od tadašnjeg provincijala fra Ignacija Mašine stiglo dopuštenje za njegovo ponovno izlaženje. ${ }^{35}$ Četiri godine kasnije tadašnji provincijal fra Ignacije Mašina odlazi u zatvor na deset mjeseci zato što je primio jedan primjerak mjesečnika Ave Maria.$^{36}$ Mjesečnik je redovito izlazio sve do 1964., kada ga se ponovno ukida zbog političke naredbe, po svoj prilici orkestrirane prvenstveno iz Zagreba, a onda i iz same Amerike.

Povodom 100. obljetnice proglašenja dogme o Bezgrešnom Začeću Marijinu 1954., fra Dobroslav Sorić, uz blagoslov tadašnjega Generala fra Johna Boccelle, na engleskom jeziku počinje izdavati mjesečnik Immaculate Conception, namijenjen mlađoj generaciji Hrvata koja nije bila najsposobnija komunicirati na hrvatskom jeziku. Taj

koji izlazi na 4 stranice... Hrvatski mjesečnik 'Križ' i formom i opsegom je manje od A. M. Nemamo prostora da nanižemo na desetke drugih magazina, koje mi primamo, a koji su mnogo manjeg formata nego je bio naš A. M. magazin." Na drugi razlog da list nije imao sadržaja fra Sorić odgovara: „Mislim da oni koji su to govorili nisu čitali mnogo brojeva magazina, jer da su zbilja pročitali par cijelih brojeva, drugačije bi govorili... Ali 'dato sed non concesso' da je to i istina, zar je bolesnika bolje ubiti nego li ga oživjeti." Na razlog da ima drugih listova, pa Ave Maria nije potreban, fra Sorić odgovara: „Na ovu primjedbu možemo odgovoriti da ima na milijune ljudi u Americi, pa onda zašto smo mi došli u Ameriku? Mi smo onda nepotrebni ovdje. Nadalje, zašto onaj vapaj tolikih stotina pretplatnika A. M. koji vapiju za svojim glasnikom! Zar ovo nije dokaz, da im duša treba te hrane koju im je magazin davao". Na primjedbu da Hrvati izumiru u Americi fra Sorić odgovara: „Ali dok nas ima u Americi dotle se moramo skrbiti za Hrvate u Americi, kako to hvalevrijedno čine i franjevci iz Chicaga sa svojim glasnikom i franjevci Konventualci sa svojim mjesečnikom 'Križ'... Ako nisu Hrvati izumrli za listove Danicu, Našu Nadu, Zajedničar, Kanadski Hrvatski Glasnik, Katolički Glasnik, Križ i druge hrvatske novine i časopise, koji izlaze ovdje u Americi, zašto su izumrli za nas?“”

34 Drugi razlog zabrane zbog financijskih poteškoća prestaje jer „Mr. Anton Zubak, koga većina članova našeg Komesarijata poznaje, dao je pismenu izjavu da će isplaćivati tisak i opremu magazina. Mi bismo preuzeli na sebe samo trošak poštarine za pisma, na koja pretplatnicima odgovaramo“.

35 Dopuštenje provincijala spominje fra Dobroslav Sorić (1967: 31).

36 Član Komesarijata fra Sebastijan Lončar na engleskom jeziku uime provincijala Ignacija Mašine piše Izvještaj o stanju u Provinciji Sv. Jeronima u Hrvatskoj (Jugoslaviji). Dokument na pet stranica nije datiran i ne zna se kome je sve dostavljen. U njemu se navodi stanje u kojem se nalaze Provincija i fratri te se spominje koji su sve franjevci trećoreci završili kao žrtve komunizma. Navodi se da je fra Augustin Šabalja strijeljan 1945., dok je fra Petar Turkalj umro u zatvoru. Ističe se tko se sve nalazio u zatvoru. Među tim imenima spominje se i ime provincijala Ignacija Mašine, koji je odslužio 10 mjeseci zbog časopisa Ave Maria (Arhiv Komesarijata). 
je glasnik bio isključivo religioznog karaktera i, čini se, dosta dobro prihvaćen. Oba časopisa (Ave Maria i Immaculate Conception) tiskala su se od 1960. u vlastitoj tiskari fra Sorića. Godine 1964. i mjesečnik Immaculate Conception prestaje izlaziti. ${ }^{37}$

\section{Razlozi konačne zabrane izdavanja Ave Marije}

Sâm fra Sorić u Vjesniku Provincije franjevaca trećoredaca glagoljaša 1967. piše da je izdavanje obaju mjesečnika prestalo zbog bolesti urednika. No, čini se da je to malo odgovaralo istini. Radilo se o politici i najvjerojatnije o pritiscima komunističkih vlasti da se fra Dobroslavu Soriću onemogući političko djelovanje u emigraciji. Godinu dana prije prestanka izlaženja njegovih časopisa, 7. svibnja 1963., tadašnji provincijal fra Nikola Gregov upućuje dosta oštro upozorenje fra Soriću, u kojem je od njega zatražio pridržavanje naziva glasnika i usredotočivanje na religiozne teme, umjesto na političke. Očito je fra Sorić na početku godine izdavao i nekakav kalendar pod nazivom Ave Maria. Stoga je provincijal zahtijevao da se za sadržaj dobije dopuštenje komesara u Americi. ${ }^{38}$ Iz provincijalova je pisma vidljivo da časopis i kalendar „nanose neprilike zajednici“.

Premda se u arhivu Komesarijata ne nalaze dokumenti koji bi dali uvid u razlog zbog kojega se fra Soriću naređuje da prestane s izdavačkim djelatnostima, ondje se ipak našao svojevrstan politički pamflet, koji je fra Sorić slao na različite adrese po Americi kao predsjednik Croatian Relief Society, neprofitne organizacije u kojoj piše protiv diktatora Tita i njegova represivnog režima. U tom pamfletu napada $\mathrm{i}$ američku Vladu, koja daje milijunske iznose pomoći Titu i njegovu režimu. Stoga apelira na novčanu pomoć, kako bi se pomoglo svima onima u Hrvatskoj koji se žele boriti protiv komunizma. ${ }^{39}$ Nema sumnje da su takvu aktivnost uočile i jugo-

37 SORIĆ 1967.

Pismo provincijala fra Nikole Gregova (Arhiv Komesarijata) od 7. svibnja 1963. glasi: Dragi oče Dobroslave! Dužnost mi je da Vas upozorim i zamolim, da se pri izdavanju glasnika i kalendara „Ave Maria“", pri izboru materijala strogo pridržavate naziva i glasnika i kalendara. Naziv $i$ glasnika i kalendara je religiozan, pa onda i sadržaj mora odgovarati nazivu, dok svaki drugi sadržaj profanira naziv glasnika i kalendara, a vjernicima ne daje ono što od njega očekuju, prema njihovu nazivu, a sigurno ni Crkva, kao zajednica vjernika, nema duhovne koristi od članaka, koji nisu vjerskog sadržaja, odnosno barem takvi da uzdižu moralni odgoj i vjersko prosvjetljenje... Ako izdajete glasnik i kalendar „Ave Maria“ kao pripadnik provincije franjevaca trećoredaca, kako stoji na kalendaru, onda se svakako pobrinite, da dobijete imprimatur od tamošnjeg predstavnika provincije, mnogopoštovanog oca Komesara. Ne ulazim u Vaše političko uvjerenje, i u Vaše shvaćanje demokracije, ali svakako svratite pažnju na to, da članci, koji izlaze u glasniku ili kalendaru, iza kojega stoji Vaše ime, odnosno još više firma provincije, ne budu takvi da zajednici nanose neprilike.

39 Pamflet (bez datuma i godine - u Arhivu Komesarijata) upućen je na adresu funkcionara Croatian Relief Society, INC, pravniku i potpredsjedniku Edwardu Servovu, fra Marijanu Soriću, blagajniku, gđi Raymond Hock, tajnici te članovima Upravnog vijeća, izdavaču Anthonyju Doshenu iz New Yorka, Stanleyju Boricu, uredniku iz Garyja u državi Indijani, kao i biznismenu Luki Grbiću u San Franciscu (Kalifornija). 
slavenske tajne službe. Stoga već 20. lipnja 1963. provincijal fra Nikola Gregov zabranjuje fra Soriću vođenje bilo kakvih akcija oko „Croatian Relief Society Inc. “40

Dana 1. travnja 1964. komesar fra Romildo Hrboka upućuje dekret fra Dobroslavu Soriću, u kojemu ga se razrješuje (s obzirom na njegovo zdravstveno stanje) službe župnika Župe Presvetog Srca Isusova u McKeesportu, službe kućnog poglavara i ekonoma te svih zaduženja i akcija oko časopisa Ave Maria. Očito fra Dobroslav Sorić nije bio upoznat s tim stvarima jer upućuje vrlo oštro pismo komesaru fra Romildu Hrboki, u kojem prosvjeduje zbog nepoštivanja odluka Provincijske kongregacije. Naime, piše kako je načuo da, pored toga što je na Kongregaciji imenovan župnikom i gvardijanom u McKeepsortu, opet postaje kapelanom..$^{41}$ Istim dekretom premješta ga se u kuću u Washingtonu na mjesto upravitelja kuće. ${ }^{42}$ Svega četiri dana poslije povlači se dekret imenovanja za Washington te ga se predlaže za kapelana u župi u McKeesportu, u kojoj je bio godinama. Uz tu odluku, od fra Dobroslava traži se da svoju farmu, koju je kupio na području Sumersetta (biskupija Altoona), prepiše na Komesarijat. Farma je, kako fra Dobroslav piše komesaru Romildu Hrboki 25. srpnja 1964., bila registrirana na Croatian Youth Center, Inc., no ipak ju je na kraju fra Dobroslav Sorić sam prodao i, izgleda, dobivenim novcem podmirio neke svoje dugove. ${ }^{43}$

\section{Collegio Commissariato Missionario Glagolitico Romano della Religiosa} Provincia Dalmato-Croata T.FRAR. di san Girolamo „Pro Oriente Slavo“ ili Glagoljaški dom „Parčić““

Franjevci su trećoreci na radu u Americi platili 30.000 USD za zgradu u kojoj se smjestio „Domus Parčić pro Oriente Slavo“, kako se navodi u Referatu o Komesarijatu sv. Franje hrvatskih trećoredaca u SAD-u. ${ }^{44}$ Taj je iznos uspio nekako zaraditi

40 Ovu naredbu provincijala spominje tadašnji komesar fra Romildo Hrboka u svom pismu fra Soriću od 10. ožujka 1964. (Arhiv Komesarijata).

41 Nažalost, kratko pismo fra Dobroslava upućeno fra Romildu Hrboki nema datuma, pa je teško reći o kojoj se kongregaciji radi.

42 Ovaj je dekret jedini dokument koji se nalazi u Arhivu Komesarijata, a koji govori o smjeni i razrješenju svih dužnosti fra Dobroslava Sorića. Dekret imenovanja upraviteljem kuće „,nauka“ u Washingtonu nosi datum 10. travnja 1964. Međutim, četiri dana kasnije, 14. travnja, fra Romildo Hrboka piše da su vijećnici Komesarijata uzeli u obzir njegovo zdravstveno stanje te se opoziva dekret o imenovanju upraviteljem kuće u Washingtonu, stoga će ga se predložiti za kapelana fra Marijanu Soriću, novom župniku Župe Presvetog Srca Isusova u McKeesportu.

43 Po svoj prilici fra Dobroslavu predstavili su da je pitsburški biskup tražio njegovu smjenu. Stoga Dobroslav Sorić odlazi k biskupu te u svom pismu od 25. srpnja 1964. fra Romildu Hrboki piše kako ga je biskup pitao na koga je registrirana farma. U vezi s farmom nije viš ništa pitao. Međutim, na pitanje što biskup ima protiv toga da Dobroslav Sorić ostane župnik, biskup mu kaže: „I have apsolutly nothing against you to be a pastor in any of your Parishes, if you are recommended by your superiors" (Arhiv Komesarijata).

44 Ovaj Referat, koji autor Romildo Hrboka naziva „skromnim“, napisan je 1969. 
i uštedjeti prvenstveno fra Albert Žagar te ostala dvojica župnika u to vrijeme: fra Dobroslav Sorić i fra Frane Karavanić. Fra Albert Žagar, kao komesar, 1943. šalje novac za kupnju kuće u Rimu u području Centocelle, Via dei Glicini 21-23.

Naime, tadašnji prokurator Reda i jedan od najvećih vizionara Provincije franjevaca trećoredaca, fra Bono Zec, od Kongregacije za redovnike i od Svetog Oca uspijeva dobiti dopuštenje za osnivanje Kolegija hrvatske provincije franjevaca trećoredaca, u kojem bi se školovali hrvatski franjevci trećoreci koji imaju tendenciju studirati orijentalistiku i proučavati glagoljicu. Ideju o tome da bi franjevci trećoreci, kao glagoljaši koji se koriste pismom sv. Ćirila i Metoda, mogli ekumenski djelovati, fra Bono Zec u svom pismu od 8. prosinca 1945. objašnjava tadašnjem prefektu kongregacije za redovnike, kardinalu Luigiju Lavitranu. U njemu kaže kako već od 1906. hrvatski franjevci trećoreci traže neku kuću u Rimu, kamo bi preselili klerike iz Zadra, kako bi se „odškolovali apostoli za istočne Slavene koji bi u duhu naše karizme privlačili braću šizmatike u krilo naše majke Katoličke Crkve" ${ }^{45}$ Dopuštenje za taj Kolegij hrvatski franjevci trećoreci dobili su 22. siječnja 1942. od Kongregacije za redovnike, Kongregacije za Istočne Crkve i Rimskog vikarijata. Ideja o kolegiju, osim što je kupljena kuća, nikada se nije ostvarila, po svoj prilici, zbog rata i njegova ishoda u Hrvatskoj. Kuća koja je trebala poslužiti svrsi Kolegija 1967. prodana je, a dobiven novac upotrijebljen je za gradnju sjemeništa u Odri.

\section{Hrvatska kuća studija u Washingtonu, samostan sv. Jeronima}

Krajem 1940-ih fra Dobroslav Sorić, kao komesar, dosjetio se zamisli o kupnji neke vlastite kuće, koja bi prvenstveno služila za odgoj vlastitih svećeničkih i redovničkih kandidata. U svom pismu braći članovima Komesarijata, datiranom 7. ožujka 1951., opisuje svoju radost da će na 25. obljetnicu djelovanja franjevaca trećoredaca u Americi ti isti franjevci otvoriti vlastitu kuću u glavnom američkom gradu Washingtonu. ${ }^{46}$ Naime, kupljena je manja kuća, uz dopuštenje Provincijala i Generala, kao i lokalnog nadbiskupa, koja je proširena i nadograđena kako bi jedan dio bio za buduće odgajanike, a drugi za svećenike i odgojitelje. Iako je kuća bila namijenjena budućim kandidatima, tijekom njezina funkcioniranja od 1951. do 2000. amo je jedan kandidat za redovnika ostao i položio svečane zavjete (fra Paško Redovniković). Budući da je vošingtonski nadbiskup zabranio

$\overline{45}$ U originalu ovoga pisma piše: „(...) per ivi formare gli apostoli ‘Pro Oriente Slavo' essendo apunto tale la missione della nostra religiosa Provincia Dalmato-Croata dalle sue origini: l'unione cioè dei nostri fratelli sciscamtici alla Santa Madre Chiesa Cattolica Romana“"(Arhiv Komesarijata).

46 U svom pismu subraći u Komesarijatu fra Dobroslav Sorić apelira na subraću da svaka župa dade vlastiti doprinos za tu kuću, a također napominje kako bi dobro bilo da braća franjevci u svojim župama govore svojim vjernicima o toj kući i potrebama (pismo u Arhivu Komesarijata). 
održavanje misa za vjernike u kućnoj kapelici, redovnici koji su ondje obitavali bili su slabo ili nikako pastoralno angažirani. Povremeno bi imali mise u kapelici Majke Božje Bistričke u nacionalnom marijanskom svetištu u Washingtonu od 1966. pa do osnutka Hrvatske katoličke misije 1985. U kući franjevaca trećoredaca ili samostanu sv. Jeronima u Washingtonu skoro trideset godina boravio je fra Teodor Badurina. Bio je prvi gvardijan te je neprestano boravio ondje do svoga povratka u Hrvatsku 1980. Kroz duže razdoblje s njime je u toj kući živio fra Paško Redovniković. U kući u Washingtonu povremeno su bili smješteni fra Sebastijan Lončar, fra Bruno Nižić, fra Ante Nižić, fra Ivan Badurina i fra Petar Runje, a fra Ilija Živković nešto više od deset godina te fra Gabrijel Badurina oko pet godina.

Na kulturnom su planu fratri, koji su prebivali u Washingtonu 1954., na nekoliko mjeseci ugostili našeg čuvenog kipara Ivana Meštrovića, koji je napravio jedan od svojih uspjelijih skulptura sv. Jeronima. Ta je skulptura u bronci postavljena ispred kuće franjevaca trećoredaca u Washingtonu 1955., gdje se nalazila sve do 1993., kada ju je fra Ilija Živković dao postaviti ispred zgrade Veleposlanstva Republike Hrvatske u Washingtonu.

\section{Pastoralno-kulturna realizacija kuće u Washingtonu ${ }^{47}$}

Fra Ilija Živković stigao je u Washington u svibnju 1984., kako bi ispitao mogućnosti i opravdanost Hrvatske katoličke misije u tom gradu. Ideju o osnivanju Misije provincijalu franjevaca trećoredaca fra Vlatku Badurini predočili su u prosincu 1983. blagopokojni kardinal Franjo Kuharić i voditelj inozemne pastve mons. Vladimir Stanković. Provincijal Badurina u siječnju 1984. priopćio je fra Iliji Živkoviću da ga je Uprava odlučila povući sa studija u Rimu i poslati u Washington.

Iako je kardinalu Kuhariću bilo jasno da u Washingtonu i okolici ne postoji velik broj Hrvata, hrvatska je Crkva smatrala da bi bilo nerazborito ne iskoristiti činjenicu da hrvatski franjevci trećoreci posjeduju vlastitu kuću u najmoćnijem gradu svijeta. Kuća na Monroe Streetu tada je bila iznajmljena američkim franjevcima trećorecima. Osim pastoralnih razloga, hrvatska je Crkva strateški promišljala jer se početkom 1980-ih već osjećalo da komunistički režim gubi na svojoj snazi. S druge strane, kardinalu Kuhariću stizala su brojna pisma iz Amerike o potrebi osnivanja Katoličke misije u Washingtonu. Najglasniji zagovornik te ideje bio je mons. Stjepan Lacković, nekadašnji tajnik blaženog Alojzija Stepinca. Tim apelima pridruživali su se i neki od istaknutijih Hrvata u Washingtonu, poput Slavka Jambrošića, Šime Letine, Bože Baćka, dr. Brune Kolege, Damira Uđbinca te pokojnog Viktora Herende i drugih.

47 O djelovanju Hrvatske katoličke misije u Washingtonu tijekom prvih deset godina fra Ilija Živković za knjigu koja je izašla u Washingtonu povodom 25. obljetnice Misije (2010.) priredio je ovaj materijal, koji se više ili manje u cijelosti donosi i u ovom tekstu. 
Hercegovački franjevci iz New Yorka (pogotovo fra Mladen Čuvalo) već su od polovine šezdesetih godina prošlog stoljeća neprestano nastojali kupiti neko zdanje i doći u Washington, međutim, neuspješno jer su uvijek nailazili na otpor lokalnog nadbiskupa. Vošingtonska je crkvena hijerarhija cijelo vrijeme vrlo pomno pazila kako se preko crkve ne bi počele širiti političke aktivnosti. U to vrijeme Jugoslavije Hrvati u SAD-u bili su na glasu buntovnika protiv Titova režima, kojima američka politička administracija, a zasigurno možemo reći i crkvena, nije previše vjerovala.

Mons. Vladimir Stanković prilično je dobro poznavao tadašnjega kardinala Jamesa Hickeyja, s kojim je, uz potporu i ugled kardinala Kuharića, unaprijed dogovorio osnivanje Katoličke misije, koja će djelovati prema dogovorenim kriterijima. Prije odlaska u Washington fra Ilija dobio je upute da ponajprije prouči postoje li opravdani pastoralni razlozi za Hrvatsku katoličku misiju u Washingtonu te da provjeri može li svećenik misionar u Washingtonu ostvariti normalnu životnu egzistenciju.

Fra Ilija stigao je u Washington iz Pittsburgha krajem svibnja 1984., gdje je na Georgetownu upisao intenzivan tečaj engleskog jezika. U vrlo kratkom vremenu okupio je skupinu uglednih Hrvata u Washingtonu, s kojom je dogovorio planove za Misiju. Dogovoreno je da će se svete mise održavati nedjeljom u nacionalnom marijanskom svetištu u Washingtonu, u hrvatskoj kapeli Majke Božje Bistričke. Već u kolovozu 1984. fra Ilija raskinuo je ugovor s američkim franjevcima koji su boravili u hrvatskoj kući te oslobodio kuću za pastoralne potrebe Hrvata. Otada se povremeno slavila sveta misa i u kućnoj kapeli. U rujnu 1984. službeno je registriran Hrvatski kulturni i duhovni centar.

Fra Ilija cijelo se vrijeme dopisivao sa svojim provincijalom, kardinalom $\mathrm{Ku}$ harićem, i mons. Stankovićem te ih izvješćivao o situaciji, naglašavajući da je takva da će hrvatski svećenik koji bi djelovao u Washingtonu morati osiguravati vlastitu egzistenciju jer od doprinosa malobrojnih vjernika neće biti u stanju živjeti. Na njegovo izvješće iz srpnju 1984. kardinal Kuharić odgovara mu 30. kolovoza 1984. ovako:

„Poštovani oče,

Iako kasno, ipak Vam želim odgovoriti na Vaše pismo od 17. srpnja og. kojim ste me opširno obavijestili o svojoj situaciji i radu u Washingtonu.

Činite ono što možete pa makar se i manja grupa vjernika okupljala nedjeljom da na svom materinskom jeziku slavi sv. Misu. Isplati se posvetiti i toj manjoj grupi vjernika. Svaki je čovjek važan i svaki je rad blagoslovljen ako čovjeku pomogne da dublje, svjesnije i istinskije živi svoju vjeru.

Stoga i zajednicu vjernika koju okupljate u kapelici Majke Božje Bistričke iskreno pozdravite s moje strane.

Žive u novoj domovini ali neka se osjećaju i tu baštinici dragocjene baštine vjere katoličke koju su Hrvati primili prije 13. stoljeća i velikim dijelom u njoj ustrajali do 
Ilija Živković - Pastoralna, socijalna, kulturna i politička djelatnost franjevaca trećoredaca...

naših dana. Samo vjera daje pravo svjetlo životu i pravi smisao Samo vjera odgaja u punini čovječnosti. Neka tu vjeru predaju i svojim mladima.

Mi ćemo za dar vjere zahvaliti na našem Nacionalnom kongresu u Mariji Bistrici, za koji vlada veliko zanimanje u narodu ali se pojavljuju i određene poteškoće. Međutim u ruke Božje.

Vama i svim hrvatskim vjernicima u Washingtonu želim svako dobro s Božjim blagoslovom, uz srdačan pozdrav u Gospodinu.

Franjo kard. Kuharić - zagrebački nadbiskup“. ${ }^{48}$

Već je ujesen 1984. fra Ilija službeno predstavljen kardinalu Hickeyju, stoga je češće odlazio k njemu te se s njime dobro sprijateljio. Negdje je početkom 1985. iz Zagreba javljeno da će se Misija osnovati prigodom dolaska kardinala Kuharića na hrvatsko nacionalno hodočašće u rujnu. Nakon što je postalo očito da će ipak doći do osnivanja Misije, počele su različite teškoće. Misija u Washingtonu nije odgovarala nečijim interesima. Dovoljno je spomenuti da je franjevačka kuća u Monroe Streetu od rujna pa do veljače 1985. triput bila obijena i opljačkana. Iako je policija barem nakon treće provale uspjela dobiti otiske, nikada nije javila eventualne rezultate. U to je vrijeme također stigao i službeni dopis pošte da se prisluškuju svi telefonski razgovori u toj franjevačkoj kući.

Prigodom proglašenja Misije u listopadu 1985. ${ }^{49}$, na kojoj je kardinal Kuharić podijelio sakrament svete potvrde osmorici krizmanika, veći dio Hrvata iz Washingtona i okolice bio je oduševljen, što se ne bi moglo reći za onaj dio politički aktivnih Hrvata koji su bili uvjereni da Misija neće ostvariti njihova očekivanja.

\section{Pastoralne aktivnosti}

Već i prije službenog osnivanja Misije, u proljeće 1985., u dogovoru s kardinalom Hickijem, podijeljena je prva pričest za sedmero prvopričesnika. Započelo se s održavanjem vjeronauka za prvopričesnike i krizmanike. Nakon službenog osnivanja Misije misa i sve druge pastoralne aktivnosti održavale su se u Misiji sv. Blaža, registriranoj u trećoredskoj kući, u kojoj je istovremeno bio i Hrvatski duhovni i kulturni centar.

Da bi Misija dobro funkcionirala, izabran je crkveni odbor, koji su činili: Ankica Pavlich, Martin Spoljaric, James Foster, Edi Cavich i Mato Tadin. Svi su, osim Mate Tadina, bili pripadnici druge ili treće generacije Hrvata, koja je zapravo imala najveći interes za postojanje Hrvatske katoličke misije u Washingtonu. Ta je

\footnotetext{
48 Ovo pismo nalazi se u osobnoj arhivi fra Ilije Živkovića.

49 Dekret proglašenja Misije nalazi se u osobnoj arhivi fra Ilije Živkovića.
} 
skupina odgovornih, vrlo časnih i u društvenom životu uspješnih ljudi na svojim ramenima nosila mnoge teškoće kroz koje je prolazila Misija.

Nakon osnivanja Misije, u listopadu 1985. hrvatski poslovni čovjek iz Manassasa, g. Karlo Milić, obećao je da će se pobrinuti za materijal potreban za preuređenje Misije, odnosno proširenje prostora kuće za vjerske sadržaje, s time da će sami vjernici izvoditi radove. Tijekom dvaju mjeseca svakog je dana desetak vjernika (najveći dio Amerikanaca hrvatskog ili nehrvatskog podrijetla) nakon posla, oko pola šest popodne, dolazilo raditi u Misiju. Svi su radovi okončani za Božić, odnosno za ponoćku 1985.

Mise su bile isključivo na hrvatskom te su Amerikanci, koji nisu znali hrvatski jezik (ali su ga znale njihove supruge i djeca), dobro to prihvatili. Već 1986. uvedena je subotnja škola za hrvatski jezik. Osim djece, tu su školu pohađale i starije osobe druge ili treće generacije Hrvata u Washingtonu. Hrvatska katolička misija postala je jedino gnijezdo gdje su Hrvati mogli imati baš vlastiti kutak u Washingtonu. Nedjeljom su Hrvati vjernici u Misiji provodili gotovo čitav dan. Počeli bi dolaziti oko 9 sati, gdje bi se uz kavu razmjenjivale informacije o situaciji u domovini, a nakon mise u 11 sati slijedio je ručak, koji su organizirali sami vjernici, te bi se redovito ostajalo do četiri ili pet sati popodne.

U početku je na misu dolazilo petnaestak do dvadesetak osoba. Prvih godina službenog djelovanja Misije bilo je dosta nepovjerenja među vjernicima koji su redovito odlazili na odmor u domovinu. Ta se vrsta vjernika plašila da dolaskom u Hrvatsku ne bude imala kakvih problema s vlastima. Politička je emigracija bila nezadovoljna jer nije bilo, za njih, adekvatnog političkog djelovanja. Fra Ilija odlučio je, a imao je i takve naputke, kako će djelatnost Katoličke misije u Washingtonu biti isključivo vjerska i kulturna, imajući na umu da se nijedan vjernik koji dođe na Misu ne mora bojati da će mu kakve tajne službe pokazati fotografiju na kojoj se nalazio u nekom „ustaškom“ centru. Takav stav odbio je dio političkih emigranata, koji su gotovo i prestali dolaziti. Međutim, već 1986. u Misiji su se počeli pojavljivati i Hrvati koji žive izvan Washingtona, iz Richmonda, Baltimorea i nekoliko mjesta iz Marylanda, a nerijetko bi navratio i tkogod iz Pensilvanije. Počelo se otkrivati i Hrvate u Washingtonu, za koje se nije znalo. Živost zajednice počeli su upotpunjavati i mladi liječnici, koji su s obiteljima počeli dolaziti na specijalizacije u Washington i okolicu. Neki od njih boravili su i po nekoliko mjeseci u Misiji dok se ne bi snašli, a mnogima se pomagalo u pronalaženju i opremanju stanova koje su iznajmljivali. Posebnu brigu i pažnju te financijsku pomoć davalo se pokojnoj gospođi Josipi Maček, supruzi predsjednika HSS-a Vladka Mačeka. U hrvatsku zajednicu u Washingtonu počeli su dolaziti djelatnici Kongresa i Senata hrvatskog podrijetla. Sve do kraja devedesetih godina prošlog stoljeća mala vjernička zajednica Hrvata u Washingtonu živjela je sretno svoj vjernički i društveni aspekt života. 
U Misiju su često svraćali hrvatski svećenici iz Kanade i Amerike, svećenici iz Hrvatske, kao i biskupi. Osim kardinala Kuharića, koji je dvaput bio u Misiji, bili su i: splitsko-makarski nadbiskup Ante Jurić, đakovačko-srijemski biskup Ćiril Kos, zadarski pomoćni biskup Ivan Prenđa, šibenski biskup Srećko Badurina, sarajevski pomoćni biskup Tomislav Jablanović, tadašnji krčki biskup Josip Bozanić, koji je nekoliko godina dolazio u Washington na odmor, pa čak i prije nego što je postao krčki biskup, kao i tadašnji sarajevski nadbiskup Vinko Puljić. Franjevačka kuća u Washingtonu ugostila je mnoštvo časnih sestara, provincijalki i generalica te redovničkih poglavara, kako iz Hrvatske, tako i iz svijeta.

\section{Socijalni i kulturni doprinos}

Nakon što je u rujnu 1984. registriran Hrvatski duhovni i kulturni centar u suradnji s Hrvatskom bratskom zajednicom i Hrvatskom katoličkom zajednicom, trećoredska kuća postala je centar u koji su počele dolaziti različite religiozne, folklorne i znanstvene skupine. Ponekad je u kući znalo prespavati i po tridesetak osoba (neki i na podu). Hrvatski kulturni i duhovni centar bio je domaćin za nekoliko hrvatskih folklornih grupa. Kad su u Washington dolazili znanstvenici, između ostalih, i pokojni Ivan Supek te različiti respektabilni povjesničari, lingvisti, pravnici itd., odsjedali su u Centru ili Misiji. U Washingtonu su se često održavali slavistički kongresi. Tako je Misija 1987. organizirala prijam za sudionike slavističkog kongresa, odnosno za tridesetak najznamenitijih hrvatskih znanstvenika koji žive i djeluju u Americi. Misija je održavala kulturne veze sa skupinom iz Kanade, koju su predvodili fra Ljubo Krasić, Ante Beljo i Gojko Šušak. Iz Kršćanske sadašnjosti naručen je čitav kontejner katekizama, Biblija za mlade, koje je Hrvatska katolička misija distribuirala širom Sjedinjenih Amričkih Država i Kanade.

U suradnji s Hrvatskom bratskom zajednicom (Bernardom Luketićem) i Hrvatskim narodnim vijećem (Matom Meštrovićem) Misija je organizirala hrvatski lobi u Kongresu. Zaposlen je bivši američki kongresnik g. Latta kako bi zastupao hrvatske interese. Te su tri ustanove spriječile podizanje spomenika Draži Mihajloviću u Washingtonu (nakon toga i Bernardu Luketiću i fra Iliji probušene su sve četiri gume na automobilima parkiranima u blizini Kongresa). Misija je u suradnji s Hrvatskom bratskom zajednicom i Hrvatskim narodnim vijećem uspjela organizirati dvije debate (hearings) u Senatu o razlici hrvatskoga i srpskog jezika. Članovi su Misije često izvješćivali, bilo kongresnike, bilo senatore, o nepravdama koje Jugoslavija čini našemu identitetu i našem narodu. Imali smo nekoliko svojih vjernika u Kongresu, a i u Senatu, a fra Ilija dosta se često, prvenstveno zbog poteškoća koje je imao na Glasu Amerike, odlazio žaliti u Kongres i Senat na nepravde, koje su mu, kao zaposleniku Glasa Amerike, glede hrvatskog jezika nanosili šefovi srpske nacionalnosti, inzistirajući na tome da nema razlike između srpskog i hrvatskog jezika. 
U Misiji je vrlo brzo stvorena solidna biblioteka, koja je imala najznačajnije radove hrvatskih umova u Americi, upotpunjena ostavštinom dijela osobne biblioteke prof. Branka Pešelja, koji je bio glavni tajnik Vladka Mačeka. Mladi intelektualci, koji su dolazili na specijalizaciju u Ameriku, nadahnjivali su se djelima do kojih nisu mogli doći u Hrvatskoj.

Što se socijalnog vida tiče, Misija je ponajprije bila utočište domaćim stanovnicima Washingtona, a posebno mladim znanstvenicima iz Hrvatske. Od 1986. do 1994. gotovo da nije bilo dana kada Misija nije imala nekog gosta. U vrijeme je komunističke opresije Misija ugostila i tadašnjeg političkog disidenta Dobroslava Paragu na više od dvaju mjeseca te su članovi Misije značajno pomogli u donošenju Senatske rezolucije o osudi postupaka jugoslavenskih vlasti protiv političkih disidenata.

\section{Djelatnosti Misije u pripremi demokracije u Hrvatskoj}

Već je 1988. u Washington počeo svraćati sve veći broj istaknutijih ljudi iz Hrvatske, pretežno iz Zagreba. Redovito su gostovali u Misiji. Primjećivalo se da su neizbježne političke promjene i u našoj domovini. Nedugo nakon dolaska u Washington fra Ilija uvidio je da je tadašnji State Department primao jedino beogradski dnevni tisak. Stoga se Katolička misija pobrinula da u State Department počne pristizati i hrvatski tisak (Večernji list, tjednik Danas te Glas Koncila).

Ljeti 1989. počeli su u Washington pristizati i prvi političari nove demokracije. Prvi je bio dr. Franjo Tuđman, koji je iz Kanade zvao da dolazi u Washington. Nije primljen u Misiju (stav voditelja Misije bio je da se političarima neće nuditi smještaj u Misiji), ali mu je ona osigurala i platila smještaj u Holiday Innu u Bethesdi. Hrvatska je katolička misija u Washingtonu također pronalazila smještaj za političare iz Hrvatske, a također i organizirala sastanke s američkim političarima. Značajno je spomenuti da je misija organizirala boravak u Washingtonu značajnim prethodnicima demokracije, poput Vlade Gotovca, Marka Veselice, Dražena Budiše i mnogih drugih, uključujući i organizaciju susreta hrvatske zajednice s Alijom Izetbegovićem 1991.

\section{Doprinosi Misije tijekom Domovinskog rata}

Kad je počeo rat u Hrvatskoj, vošingtonska zajednica postala je kao velika obitelj. Svi su pokupovali neke specijalne radije i svakodnevno osluškivali vijesti Radio Zagreba, koji je u Misiju svakodnevno slao faksom na desetke stranica vijesti. Jedna skupina mladih intelektualaca i studenata u Washingtonu svake je večeri u Misiji prevodila vijesti, koje su se slale različitim uredništvima američkih listova i e-poštom prosljeđivale sveučilištima i američkim intelektualcima. Pisale su se peticije, nazivali su se dnevni listovi: Washington Post, New York 
Times, Washington Times, različiti televizijski kanali i voditelji. Članovi Misije koordinirali su organizaciju hrvatskih prosvjeda ispred Kongresa te organizirali dvomjesečni prosvjed Hrvata iz Washingtona i okolice sa svijećama ispred Bijele kuće. Svi su bili u šoku te su se osjećali bespomoćno. U prikupljanju pomoći u robi i hrani priključivali su se i vošingtonski crnci. Poslano je nekoliko kamiona robe i hrane $u$ Hrvatsku te pozamašna novčana pomoć. ${ }^{50}$

Budući da su neki članovi Misije imali izravnu vezu do tadašnjeg predsjednika Georgea Busha s pomoću njegove šefice kabineta gđe Rose Zammaria, Misija je i sa svoje strane informirala Bijelu kuću. Nažalost, u vezi s mnogim informacijama predsjednik je Bush više vjerovao svome savjetniku za nacionalnu sigurnost Lawrenceu Eaglebergeru negoli Hrvatima. U isto se vrijeme orkestriralo s mnogim utjecajnim Hrvatima u Americi, svatko po svojim kanalima, upoznavalo sa situacijom kongresnike i senatore. Možda su ti napori u konačnici i urodili plodom, a možda i nisu. Fra Ilija posebno je surađivao s Američkom biskupskom konferencijom, koju je svakodnevno detaljno izvješćivao o događajima. Također je često izvješćivao tadašnjega senatora Josepha (Joa) Bidena, koji je bio na čelu senatskog Odbora za vanjsku politiku.

Nakon američkog priznanja Republike Hrvatske članovi Misije gotovo su s istim intenzitetom nastavili informirati američku javnost o događajima u Bosni i Hercegovini. ${ }^{51}$ Neposredno nakon predsjedničkih izbora, na kojima je izabran Bill Clinton, voditelj Misije fra Ilija Živković pozvan je u Little Rock (Arkansas), gdje je tranzitnom timu Clinton - Gore govorio o situaciji u Bosni i Hercegovini 17. prosinca 1992. ${ }^{52}$ Kako je rat odmicao, tako su u Katoličku misiju u Washingtonu pristizali novi ljudi, a među njima i ranjeni muslimanski pripadnici HVO-a, koji su, između ostaloga, uvijek sudjelovali i na Misi.

Već je u lipnju 1992. u Washington stigao neslužbeni predstavnik Republike Hrvatske dr. Frane Vinko Golem. Misija mu je pomagala u snalaženju i uspostavi kontakata u američkoj administraciji. Neposredno nakon što je Amerika priznala Republiku Hrvatsku u travnju 1992. voditelj Misije pomogao je hrvatskoj Vladi u pronalaženju i otkupljivanju našeg današnjeg veleposlanstva. Nakon što je u Washington stigao prvi hrvatski veleposlanik dr. Petar Starčević, fra Ilija je Živković 1993., u dogovoru s Provincijom, ponudio kip sv. Jeronima, djelo slavnog kipara Ivana Meštrovića - koji je stajao ispred franjevačke kuće i Misije - a inače je vlasništvo hrvatskih franjevaca trećoredaca, kako bi se postavio ispred

50 Dio aktivnosti Hrvatske katoličke misije u Washingtonu opisan je u knjizi Vladimira Gossa (GOSS 1994).

51 O posebnom zalaganju fra Ilije Živkovića za Bosansku Posavinu, između ostaloga, pisao je i istaknuti hrvatski novinar Danko Plevnik u svojoj knjizi Smisao Bosne (1997).

52 Govor fra Ilije Živkovića tranzicijskom timu Clinton - Gore objavljen je u Zajedničaru od 20. siječnja 1993., str. 4. 
hrvatskog veleposlanstva, čime se željela usmjeriti pozornost američkih građana prema našem veleposlanstvu.

\section{Zaključni osvrt}

Iako nepripremljeni za pastoralne aktivnosti, franjevci trećoreci glagoljaši vrlo uspješno pastoralno djeluju u Sjedinjenim Američkim Državama tijekom 78 godina. Štoviše, osebujniji su i maštovitiji u duhovnoj brizi za hrvatske doseljenike negoli su to bili domaći (američki) svećenici, koji su pastorizirali neslavensko stanovništvo. Franjevci su trećoreci uspješno čuvali duhovne vrijednosti „staroga kraja" $i$ odmjereno prihvaćali pastoralne zahtjeve lokalne crkve i lokalnog episkopata. U pastoralnom su radu trećoreci prednjačili u organizaciji različitih društava, koja su bila kako pobožne, tako i socijalno-kulturne naravi. Vrlo su dobro surađivali s ograncima Hrvatske bratske zajednice u pokušajima očuvanja svoje kulture i tradicije. U tim se aktivnostima posebno isticao fra Dobroslav Sorić. Također su se pokazali kao izvrsni upravitelji župa i uspješni menadžeri. Od 19 fratara, koji su tijekom 78 godina prisutnosti franjevaca trećoredaca glagoljaša u Americi, može se slobodno reći da su trojica prvih pionira, fra Stanko Dujmović, fra Albert Žagar i fra Dobroslav Sorić, ostavili neizbrisiv pečat trećoredsko-glagoljaške duhovne i kulturne tradicije na području Pittsburgha, odnosno Pensilvanije. Ta se trojica pokazuju kao izraziti rodoljubi, požrtvovni članovi Provincije te pravi izdanci trećoredaca glagoljaša, koji su sa svojim narodom oduvijek bili osjetljivi na njegovu kulturu, tradiciju i običaje.

Upravo u tome kontekstu imamo fra Alberta Žagara, koji angažira hrvatskog slikara Vanku i na američkom teritoriju u sakralnom prostoru omogućuje da običaji i tradicija Hrvata u Pittsburghu postanu vrijedni divljenja i poštovanja. Taj isti Albert Žagar, podrijetlom Slovenac, živi ekstremno pokornički kako bi uštedio novac potreban njegovoj Provinciji s ciljem pronalaženja kuće u Rimu, koja će biti sjedište Kolegija „Pro Oriento slavo“ ili „Glagoljaški dom Parčićc“.

Drevni su franjevci trećoreci glagoljaši, osim po pokorničkom načinu življenja te korištenju glagoljice u liturgiji, bili poznati i kao prosvjetitelji. U devetnaestom stoljeću postoji barem dvadesetak istaknutih trećoredaca koji su postizali titule doktora znanosti i predavali na različitim školama. ${ }^{53}$ Među njima su se isticali Dragutin Parčić, Alfonso Volarić i Stanko Dujmović. Riječ je o skupini koja je očito imala utjecaja i na mladoga Dobroslava Sorića, koji je u duhu prosvjetiteljstva počeo izdavati svoje mjesečnike Ave Maria i Immaculate Conception. Ti su mjesečnici među Hrvatima u Americi bili vrlo popularni, međutim zbog Sorićeve su političke orijentacije i ugašeni.

53 GREGOV 1990: 27. 
Što se političke djelatnosti u Americi tiče, franjevci trećoreci, s izuzetkom fra Dobroslava Sorića, djelovali su patriotski, ali se nisu direktno miješali u politiku. Izrazitiju političku aktivnost franjevci trećoreci u Americi započinju krajem 1980ih i, naravno, nakon agresije na Hrvatsku 1991. Zaključno bi se moglo reći da je uloga franjevaca trećoredaca u Americi, a posebno u Pittsburghu i okolici bila uistinu velika i upečatljiva na svim razinama: duhovnoj, pastoralnoj, socijalnoj, kulturnoj, prosvjetiteljskoj te donekle i na političkoj.

\section{Bibliografija}

\section{Izvori}

Arhiv franjevačkog samostana sv. Marije, Glavotok:

Spisi 3 (1901.-1930.)

Arhiv Komesarijata franjevaca trećoredaca glagoljaša. Samostan sv. Franje u Odri (Zagreb).

Arhiv Provincijalata franjevaca trećoredaca glagoljaša, Zagreb:

Knjiga Uspomena II. iz 1906. Dnevnik fra Stanka Dujmovića.

\section{Literatura}

BADURINA, Anđelko. 1998. Trećoredci na Ksaveru. U Svetište svetoga Franje Ksaverskoga u Zagrebu. Povodom 75. obljetnice dolaska franjevaca trećoredaca glagoljaša u Zagreb, ur. Anđelko Badurina, Tomislav Premerl, Božo Sučić, 17-23. Zagreb: Provincijalat franjevaca trećoredaca glagoljaša.

Centennial (1847-1947) - The life and work of the Croatian People in Allegheny County, Pennsylvania - Presented in conjunction with the Twentieth Anniversary of the Croatian Franciscan Fathers in Western Pennsylvania. Prepared by Rev. Boniface Soric, T.FRAR. The Croatian Historical Research Bureau, 1947.

DOMENCIC, Richard. 2000. The Murals of Maxo Vanka-St. Nicholas Church Millvale. Pittsburgh.

GOSS, Vladimir. 1994. Washingtonska fronta. Zagreb: Hrvatska sveučilišna naklada.

GREGOV, Nikola. 1965. In memoriam fra Stanka dr. Dujmovića (27. I. 1866. - 25. II. 1940.) [I-II]. Vjesnik franjevaca trécoredaca glagoljaša III/2: 37-40; III/3: 66-73.

GREGOV, Nikola. 1990. Školovanje u provinciji franjevaca trećoredaca glagoljaša [Novaja i vethaja 1]. Zagreb: Provincijalat franjevaca trećoredaca.

HARRIS, Randy. 1981. Rediscovering Murals leave haunting images of immigrants and industrialists. U Murals and Miners in Millvale, Pittsburgh. Pittsburgh: The Mill Hunk Herald.

HRBOKA, Romildo. 1969. Skromni referat o Komesarijatu Sv. Franje Hrvatskih Trećoredaca u USA. Koga volimo zvati NAŠA DJELA. Pittsburgh.

Hundred-th Anniversary of St. Nicolas Croatian Chruch Millvale (1900-2000). 2000. Pittsburgh. 
MAROHNIĆ, Josip. 1902. Popis Hrvata u Americi - Kratki opis Sjedinjenih Država sa zemljovidnim kartama. Allegheny: Naklada Prve Američke Hrvatske Knjižare.

PLEVNIK, Danko. 1997. Smisao Bosne. Zagreb: Jesenski i Turk.

RUNJE, Petar. 2007. Povijest Provincije franjevaca trećoredaca-glagoljaša dvadesetog stoljeća (strojopis). Ogulin: vlastita naklada.

Sacred Heart Parish 50-th Golden Jubilee and Solemn Dedication of the New Church. 1956. McKeesport.

SORIĆ, Dobroslav. 1966. 40-ta godišnjica dolaska redovnika naše Provincije u SAD. Vjesnik franjevaca trećoredaca glagoljaša IV/5: 101-105.

SORIĆ, Dobroslav. 1967. Život i rad naših svećenika na župi sv. Nikole u Millvalu. Vjesnik franjevaca trećoredaca glagoljaša $\mathrm{V} / 1: 5-9$.

Spomen knjiga u proslavu 30 godišnjice Hrv. R. K. Crkve sv. Nikole u U. S. 1901.-1931. Pittsburgh.

Spomen knjiga zlatnog jubileja ili 50. godišnjice prve hrvatske rimokatoličke župe Svetoga Nikole 1326 E. Ohio St. Pittsburgh 12, Pa. 1894-1944 (Souvenir of the Golden Jubilee of St. Nicolas Croatian R. C. Church. Pittsburgh, Pa. 1894-1944. Prepared by Dobroslav Sorić.

Spomen knjiga zlatnog jubileja Prve Hrvatske Rimokatoličke Župe sv. Nikole. 1944. Pittsburgh.

St. Nicolas Roman Catholic Church North Side, Pittsburgh, PA - 100th Anniversary 1894-1994 - First Croatian Parish in America. Prepared by Fr. Grgo Sikiric, T.FRAR.

ŽAGAR, Albert. 1950. Spomen knjiga 50-godišnjici opstanka Hrvatske Rimokatoličke Crkve ,Svetoga Nikole“ u Millvale. Millvale.

ŽIVKOVIĆ, Ilija. 1993. Govor fra Ilije Živkovića tranzicijskom timu Clinton/Gore. Zajedničar, 20. I. 1993., 4.

\section{Pastoral, Social, Cultural and Political Activity of the Glagolitic Tertiary Franciscans in the United States of America}

The present paper offers a summary of the 78 years long work and activity of the Glagolitic tertiary Franciscans in the United States of America. First, an insight is given into the historic decision of the tertiary Glagolitic friars to follow their people and emigrate to the United States. The decision was made after the second great wave of emigration of the Croatian population between the two world wars. The decision had two goals: to follow the emigrating groups of their own people and to maintain the emigrants in the faith and culture of their old country and also to help the Province with the building of a monastery in Zagreb. After that, the paper deals with the pastoral activities of the tertiaries in the parishes entrusted to them. Since their arrival in America until they left, the tertiaries were administering three parishes in Pittsburgh and its area: the parish of St. Nicholas in northern part of 
Pittsburgh, the parish of St. Nicholas in Millvale and the parish of the Holy Heart of Jesus in Mckeesport. The paper offers a historical survey of the building of the churches as well as of the spiritual, social and cultural activity in the parishes.

The second part deals with the most important cultural and edifying activities of the tertiary Franciscans who left a significant mark in Pittsburgh and its area. First, the works of the Croatian painter Maximilian Vanke in the church of St. Nicholas in Millvale are described. The church's interior, which was entered in the national register of historic places in America, is decorated with various motifs from Croatia and also with depictions of the hard life of the Croatian emigrant in America. Another cultural and edifying activity of the tertiaries this paper describes, are the two monthly journals that father Dobroslav Sorić was publishing through many years. The journal Ave Maria appeared in Croatian language, and the second one entitled Immaculate Conception in English. Both journals were of religious nature, the Ave Maria was intended for the Croats of the first generation, whereas the Immaculate Conception was writing for the children of Croatian emigrants who couldn't speak Croatian very well any more. The difficulties the editor and publisher of these journals had to experience thanks to his occasional criticism at the communist regime in Yugoslavia are also dealt with in the paper. Since the tertiaries in America, organised in a ecclesiastical territorial unit called Commissariat, were patrons who supported financially single projects the Province couldn't finance, the paper explores the American support for one of the greatest achievements of the Franciscan Third Order in Rome, i. e. obtaining the permission for the Provincial College ,pro Oriente Slavo“ or „Glagoljaški dom Parčić“(Parčić Glagolitic house).

The third part of the paper describes the tertiary house in Washington that was bought primarily to serve as a seminary, but was later, in the 1980's, used for the foundation of the Croatian Catholic Mission. The paper portrays the first 10 years of the Mission's work in Washington exploring its pastoral, cultural and social activities and, last not least, the efforts related to the establishment of the independent Croatia.

Keywords: franciscans of the Third Order Regular, United States of America, Pittsburgh, Croatian Parish, Maksimilijan Vanka, journal Ave Maria

Ključne riječi: franjevci trećoreci, Sjedinjene Američke Države, Pittsburgh, hrvatska župa, Maksimilijan Vanka, časopis Ave Maria

llija Živković Katolički bogoslovni fakultet Sveučilišta u Zagrebu HR-10000 Zagreb, Vlaška ul. 38 


\section{FILOZOFSKI FAKULTET SVEUČILIŠTA U ZAGREBU \\ ZAVOD ZA HRVATSKU POVIJEST \\ INSTITUTE OF CROATIAN HISTORY \\ INSTITUT FÜR KROATISCHE GESCHICHTE}
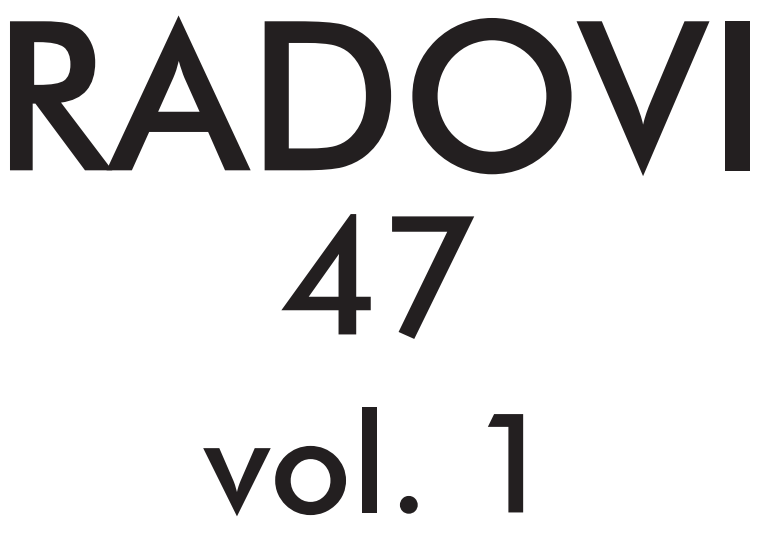

ZAVOD ZA HRVATSKU POVIJEST

FILOZOFSKOGA FAKULTETA SVEUČILIŠTA U ZAGREBU

\section{PF press \\ ZAGREB 2015.}




\title{
RADOVI ZAVODA ZA HRVATSKU POVIJEST FILOZOFSKOGA FAKULTETA SVEUČILIŠTA U ZAGREBU
}

\author{
Knjiga 47, vol. 1
}

\author{
Izdavač / Publisher \\ Zavod za hrvatsku povijest \\ Filozofskoga fakulteta Sveučilišta u Zagrebu \\ FF-press \\ Za izdavača / For Publisher \\ Vlatko Previšić \\ Glavni urednik / Editor-in-Chief \\ Hrvoje Gračanin \\ Izvršna urednica / Executive Editor \\ Inga Vilogorac Brčić \\ Uredništvo / Editorial Board
}

Bruna Kuntić-Makvić (stara povijest/ancient history), Zrinka Nikolić Jakus (srednji vijek/ medieval history), Hrvoje Petrić (rani novi vijek/early modern history), Željko Holjevac (moderna povijest/modern history), Tvrtko Jakovina (suvremena povijest/contemporary history),

Silvija Pisk (mikrohistorija i zavičajna povijest/microhistory and local history),

Zrinka Blažević (teorija i metodologija povijesti/theory and methodology of history)

Međunarodno uredničko vijeće / International Editorial Council

Denis Alimov (Sankt Peterburg), Živko Andrijašević (Nikšić), Csaba Békés (Budapest), Rajko Bratož (Ljubljana), Snježana Buzov (Columbus, Ohio), Svetlozar Eldarov (Sofija), Toni Filiposki (Skopje), Aleksandar Fotić (Beograd), Vladan Gavrilović (Novi Sad), Alojz Ivanišević (Wien),

Egidio Ivetić (Padova), Husnija Kamberović (Sarajevo), Karl Kaser (Graz),

Irina Ognyanova (Sofija), Géza Pálffy (Budapest), Ioan-Aurel Pop (Cluj),

Nade Proeva (Skopje), Alexios Savvides (Kalamata), Vlada Stanković (Beograd), Ludwig Steindorff (Kiel), Peter Štih (Ljubljana)

Izvršna urednica za tuzemnu i inozemnu razmjenu / Executive Editor for Publications Exchange Kristina Milković

Tajnik uredništva / Editorial Board Assistant

Dejan Zadro

Adresa uredništva/Editorial Board address

Zavod za hrvatsku povijest, Filozofski fakultet Zagreb, Ivana Lučića 3, HR-10 000, Zagreb

Tel. ++385 (0)1 6120 150, 6120 158, faks ++385 (0)1 6156879

Časopis izlazi jedanput godišnje / The Journal is published once a year

Časopis je u digitalnom obliku dostupan na / The Journal in digital form is accessible at Portal znanstvenih časopisa Republike Hrvatske „Hrčak“ http://hrcak.srce.hr/radovi-zhp

Financijska potpora za tisak časopisa / The Journal is published with the support by

Ministarstvo znanosti, obrazovanja i športa Republike Hrvatske

Časopis je indeksiran u sljedećim bazama / The Journal is indexed in the following databases:

Directory of Open Access Journals, EBSCO, SCOPUS, ERIH PLUS 
Naslovna stranica

Iva Mandić

Grafičko oblikovanje i računalni slog

Marko Maraković

Lektura

Samanta Paronić

Tisak

Web2tisak, Zagreb

Naklada

250 primjeraka

Časopis je u digitalnom obliku dostupan na Portalu znanstvenih časopisa Republike Hrvatske ,Hrčak“ http://hrcak.srce.hr/radovi-zhp

The Journal is accessible in digital form at the Hrcak - Portal of scientific journals of Croatia http://hrcak.srce.hr/radovi-zhp 


\section{RADOVI 47}

\section{vol. 1}

ZaVoda za hrVAtSku poviJest FILOZOFskoga fakulteta SVeuČILIŠTA u Zagrebu 


\title{
Tematski blok / Themed issue
}

\section{TREĆOREDSKA GLAGOLJAŠKA TRADICIJA U EUROPSKOM KONTEKSTU TERTIARY GLAGOLITIC TRADITION IN EUROPEAN CONTEXT}

\author{
Radovi međunarodnoga znanstvenog skupa \\ održanoga 27. i 28. IX. 2013. na Hrvatskom katoličkom sveučilištu u Zagrebu \\ u organizaciji \\ Provincije franjevaca trećoredaca glagoljaša u Zagrebu, Hrvatskoga katoličkog \\ sveučilišta u Zagrebu, Filozofskoga fakulteta Sveučilišta u Zagrebu - Odsjek za \\ povijest, Filozofskoga fakulteta Sveučilišta u Splitu - Odsjek za povijest, Instituta \\ za povijest umjetnosti u Zagrebu i Staroslavenskoga instituta u Zagrebu \\ Proceedings of the International Scientific Conference \\ held on 27th and 28th September 2013 at the Catholic University of Croatia in Zagreb \\ and organized by \\ the Province of the Glagolitic Friars of the Third Order Regular, Catholic University \\ of Croatia in Zagreb, Faculty of Humanities and Social Sciences of the University \\ of Zagreb - Department of History, Faculty of Humanities and Social Sciences of \\ the University of Split - Department of History, Institute of Art History, \\ and Old Church Slavonic Institute
}

Gosti urednici / Guest editors

\author{
Ivan BOTICA \\ Tomislav GALOVIĆ \\ Kristijan KUHAR
}

